\title{
Mycotoxin Decontamination Aspects in Food, Feed and Renewables Using Fermentation Processes
}

\author{
Grazina Juodeikiene, Loreta Basinskiene, \\ Elena Bartkiene and Paulius Matusevicius
}

Additional information is available at the end of the chapter

http://dx.doi.org/10.5772/46184

\section{Introduction}

Mycotoxins are secondary metabolites produced by a wide variety of filamentous fungi, including species from the genera Aspergillus, Fusarium and Penicillium. They cause nutritional losses and represent a significant hazard to the food and feed chain. Humans have long been exposed to mycotoxins by several different routes: directly, via foods of plant origin; by air (both indoors and outdoors); or indirectly, through foods of animal origin. The economically most important mycotoxins in foods and feeds are aflatoxins, ochratoxin A and patulin produced mainly by Aspergillus and Penicillium spp. and Fusarium toxins: type A and B trichothecenes, zearalenone and fumonisins (Table 1) [1, 2]. With the exception of T-2 and HT-2 and ergot or the sum of its individual alkaloids in unprocessed cereals and cereal products all mentioned mycotoxins have been regulated in the EU quite detailed in regulations (EC) No. 1881/2006 and 105/2010.

Occurrence of mycotoxin contamination in foods is more prevalent in the tropical and subtropical countries resulting in acute and chronic mycotoxicoses in humans and animals. Wild [3] reported that many West African countries, over $98 \%$ of the tested people were positive to aflatoxin-DNA adducts indicating aflatoxin exposure in the population. The importance of this situation is highlighted with an outbreak of aflatoxicosis as 2004 in Kenya [4] and a report on impaired child growth in Benin caused by post weaning exposure to aflatoxins [5]. Many of the developed countries have regulations for mycotoxins in grains and its products, because at least $60 \%$ of the food produced and consumed in the world originates from cereal crops such as rice, wheat, corn, barley,rye, sorghum and oats. However, the risk of mycotoxin exposures continues in the developing countries due to lack of food security, poverty and malnutrition $[5,6]$. 


\begin{tabular}{|c|c|c|c|c|c|}
\hline \multicolumn{2}{|c|}{ Mycotoxin } & Commodity & Genus & Species & Disease/mode of \\
\hline Ergot alkaloids & $\begin{array}{l}\text { Ergotamine, } \\
\text { ergometrine } \\
\text { Ergosine, } \\
\text { ergocristine } \\
\text { Ergocryptine, } \\
\text { ergocornine }\end{array}$ & $\begin{array}{l}\text { Cereals } \\
\text { Pearl millet }\end{array}$ & Claviceps & $\begin{array}{l}\text { purpurea } \\
\text { fusiformis }\end{array}$ & $\begin{array}{l}\text { Necrose of limbs - } \\
\text { St. Anthony's fire } \\
\text { Vasoconstrictive } \\
\text { properties } \\
\text { Gangrenous and } \\
\text { colvulsive ergotism }\end{array}$ \\
\hline $\begin{array}{l}\text { Aflatoxin } \\
(\mathrm{AFT}) \\
(\mathrm{AFM})\end{array}$ & $\begin{array}{l}\mathrm{B} 1, \mathrm{~B} 2 \\
\mathrm{G} 1, \mathrm{G} 2 \\
\mathrm{M} 1, \mathrm{M} 2\end{array}$ & $\begin{array}{l}\text { Cereals, nuts } \\
\text { Spices, figs } \\
\text { Milk }\end{array}$ & Aspergillus & $\begin{array}{l}\text { flavus } \\
\text { parasiticus } \\
\text { nominus } \\
\text { pseudotamarii }\end{array}$ & $\begin{array}{l}\text { Carcinogenic } \\
\text { Liver cancer } \\
\text { Immune } \\
\text { suppressive }\end{array}$ \\
\hline $\begin{array}{l}\text { Ochratoxin } \\
\text { (OTA) }\end{array}$ & $\begin{array}{l}\text { A } \\
\text { B }\end{array}$ & $\begin{array}{l}\text { Cereals } \\
\text { Wine } \\
\text { Coffee } \\
\text { Spices }\end{array}$ & $\begin{array}{l}\text { Aspergillus } \\
\text { Penicillium }\end{array}$ & $\begin{array}{l}\text { ochraceus } \\
\text { carbonarius } \\
\text { verrucosum }\end{array}$ & $\begin{array}{l}\text { Neurotoxic } \\
\text { Nephrotoxic } \\
\text { Kidney damage } \\
\text { and cancer } \\
\text { Immune } \\
\text { suppressive }\end{array}$ \\
\hline $\begin{array}{l}\text { Type B } \\
\text { trichothecenes }\end{array}$ & $\begin{array}{l}\text { DON } \\
\text { (Vomitoxin) } \\
\text { ADON, NIV } \\
\text { ANIV }\end{array}$ & Cereals & Fusarium & $\begin{array}{l}\text { graminearum } \\
\text { culmorum } \\
\text { acuminatum } \\
\text { crookwellence } \\
\text { arenaceum }\end{array}$ & $\begin{array}{l}\text { ATA (alimentary } \\
\text { toxic leukopenia) } \\
\text { Immunotoxic } \\
\text { Acute toxicity }\end{array}$ \\
\hline $\begin{array}{l}\text { Type A } \\
\text { trichothecenes }\end{array}$ & $\begin{array}{l}\text { T-2 } \\
\text { HT-2 }\end{array}$ & $\begin{array}{l}\text { Small grains } \\
\text { Cereals }\end{array}$ & Fusarium & $\begin{array}{l}\text { poae } \\
\text { sporotrichioides }\end{array}$ & $\begin{array}{l}\text { Acute toxicity } \\
\text { linked to ATA } \\
\text { Immunotoxic } \\
\text { Immune system } \\
\text { and hematological } \\
\text { disorders }\end{array}$ \\
\hline \begin{tabular}{|l} 
Zearalenone \\
(ZEA)
\end{tabular} & & Cereals & Fusarium & $\begin{array}{l}\text { graminearum } \\
\text { culmorum } \\
\text { cerealis } \\
\text { avenaceum } \\
\text { equiseti }\end{array}$ & $\begin{array}{l}\text { Estrogenic effects } \\
\text { Reproductive } \\
\text { disorders } \\
\text { Effects endocrine } \\
\text { system }\end{array}$ \\
\hline $\begin{array}{l}\text { Fumonisin } \\
\text { (FUM) }\end{array}$ & $\begin{array}{l}\text { FB1 } \\
\text { FB2 }\end{array}$ & $\begin{array}{l}\text { Corn } \\
\text { Cereals } \\
\text { Multiple crops }\end{array}$ & $\begin{array}{l}\text { Fusarium } \\
\text { (formerly) } \\
\text { F.moniliforme }\end{array}$ & $\begin{array}{l}\text { proliferatum } \\
\text { subglutinans }\end{array}$ & $\begin{array}{l}\text { Esophageal cancer } \\
\text { Sphingolipid } \\
\text { methabolism } \\
\text { disruption } \\
\text { Immune } \\
\text { suppression }\end{array}$ \\
\hline
\end{tabular}

Table 1. Most important parent mycotoxins for cereal products, their occurrence, primary fungus producer and mode of action 
Several approaches have been developed for decontamination of mycotoxins in foods [7, 8]. Principally, there are three possibilities to avoid the harmful effect of contamination of food and feed caused by mycotoxins:

1. prevention of contamination;

2. decontamination of mycotoxin-containing food and feed; and

3. inhibition or absorption of mycotoxin content of consumed food into the digestive tract.

The most obvious measure as to prevent mycotoxin production is in general to reduce the moisture content of the commodity to the equivalent of less than 0.65 water activity (e.g. for cereals $<14.5 \%$ moisture by weight) direct after harvest. To minimize mycotoxin contamination can also be achieved as to limit bird and insect damage. Create also anaerobic conditions by storage and promote crop rotation to minimize the carry-over of moulds from one year to the next. Many of these recommendations can be found in documents of the Codex Alimentarius (CODEX STAN 193). Other useful documents are the codes of practice for the prevention and reduction of mycotoxin contamination in cereals, including annexes on OTA, ZEA, FUM and trichothecenes. Together with a suitable Hazard Analysis Critical Control Points (HACCP) and reliability procedures and following properly reporting systems such as RASFF (Rapid Alert System for Food and Feed) in Europe and RFR (Reportable Food Registry) in the US, health and safety measures in food and feed are optimum served by preventing and controlling the formation of mycotoxin.

The approach of prevention is doubtless also to breed cereals and other food and feed plants for resistance to mould infection and consequently exclude mycotoxin production. Particularly in breeding wheat and corn, significant improvement of resistance has been achieved. The slow-moving research however in the breeding field to culture resistant crops even through marker-assisted breeding (MAS),seems to be an endless task since up until now moulds have been a step ahead of breeders. The identification of microbial species (and genes coding enzymes degrading mycotoxins) allows transfer of these genes into plants and production of such enzymes by transgenic plants. In this way, the safety problems connected with the use of live microorganisms may be avoided. Another practical approach to prevention of mycotoxin contamination is the inhibition of the growth of molds and their production of mycotoxins. First, optimal harvesting, storage and processing methods, and conditions may be successful in prevention of mold growth. Although the primary goal is the prevention of mycotoxin contamination, mycotoxin formation appears to be unavoidable under certain adverse conditions. Treatment of grains by some chemicals to prevent mycotoxin formation is also possible but not desirable in view of a.o. the chemophobia of Europeans and the far-reaching legislation in the EU to restrict herbicides and pesticides with 'REACH' (REACH = Registration, Evaluation, Authorisation and restriction of Chemicals), effective as of 1 June 2007.

Most of these compounds work by inhibiting fungal growth. For example, approximately one hundred compounds have been found to inhibit aflatoxin production. Two extensively studied inhibitors of aflatoxin synthesis are dichlorvos (an organophosphate insecticide) and caffeine. As reported in reference [8] some surfactants have been found to suppress the 
growth of Aspergillus flavus and aflatoxin synthesis. When contamination cannot be prevented, physical and chemical decontamination methods have been employed (such as for ergot physically) with varying success in the past, principally for feed. Whichever decontamination strategy is used, it must meet some basic criteria:

1. the mycotoxin must be inactivated or destroyed by transformation to non-toxic compounds;

2. fungal spores and mycelia should be destroyed, so that new toxins are not formed;

3. the food or feed material should retain its nutritive value and remain palatable;

4. the physical properties of raw material should not change significantly; and it must be economically feasible / the cost of decontamination should be less than the value of contaminated commodity.

Mycotoxin decontamination by physical and chemical methods has been reviewed extensively in several papers $[7,9,10]$. Partial removal of mycotoxin may be achieved by dry cleaning of the grain and in the milling process, as well. Milling led to a fractionation, with increased level of mycotoxin in bran and decreased level in flour. The majority of mycotoxins are heat-stable so heat treatment, usually applied in food technology, does not have significant effect on the mycotoxin level. Efforts were made in several countries to find an economically acceptable way of destruction of mycotoxins into non-toxic products using different chemicals such as alkali and oxidative agents. Although such treatment reduces nearly completely the mycotoxin concentration, these chemicals also cause losses of some nutrients and such treatment is too drastic for e.g. grain destined for food uses. Many physical adsorbents have been studied and are available as commercial preparations as animal feed additives. However, many of these adsorbents can bind to only a small group of toxins while showing very little or no binding to others [9]. Although the different methods used at present have been to some extent successful, most methods have major disadvantages, starting with limited efficacy to losses of important nutrients and generally with high costs. Because the EU does not allow chemical treatment methods anyway, manoeuvrability is limited.

More recently, biological decontamination and biodegradation of mycotoxins with microorganisms or enzymes have been used [11, 12]. Many species of bacteria and fungi have been shown to enzymatically degrade mycotoxins [13-19]. In this case no harmful chemicals were used, so no significant losses in nutritive value and palatability of decontaminated food and feed occurred. Today, ruminants appear to be a promising potential source of microbes or enzymes for use in the biotransformation of fungi and/or there mycotoxins they create. Biological decontamination of fungi/mycotoxins by microorganisms is reviewed in some papers $[8,13,16,20,21]$, however, there are no many reviews on decontamination of fungi/mycotoxins by microorganisms involved in food fermentation and its implications. Fermentation is one of the easiest and cheapest means of food preservation in addition to imparting nutritional and organoleptic benefits to fermented foods. Fermentation is effected by the natural microbiota of raw materials, microorganisms attached to the fermentation equipments or from externally added starter cultures. Yeasts, especially S. cerevisiae and Candida krusei, and lactic acid bacteria (LAB) occur as part of natural microbial population in spontaneous food fermentation and as 
starter cultures in the food and beverage industry [22]. In addition, yeasts have been fed to animals for more than a century and commercial yeast products are being specifically produced on a commercial scale for animal feeding [23]. Hence, yeasts and LAB have immense potential as tools in tackling the problem of fungi/mycotoxins in cereal-based foods and in animal feed.

However, question remains on the toxicity of products of enzymatic degradation and undesired effects of fermentation with non-native microorganisms on the quality of food [21]. In this chapter the biocontrol of aflatoxins, trichothecenes (type A and B), zearalenone, fumonisins, ochratoxins and patulin by bacteria, fungi and yeasts will be discussed more in depth to fill the existing gaps and to develop further proper management practices using biocontrol agents to ensure food safety and to protect consumer's health.

\section{Possible approaches of microorganisms and enzymes to biodegradation of mycotoxins}

One of the most frequently used strategies for biodegradation of mycotoxins includes isolation of microorganisms able to degrade the given mycotoxin and treatment of food or feed in an appropriate fermentation process. From a food safety point-of-view, fermentation with microorganisms commonly used in food production (fermentation with lactic acid bacteria, alcoholic fermentation, traditional fermentation of vegetable protein used in South Asia, etc.) should be preferred.

Knowledge of enzymes that take part in degradation of mycotoxins opens some new approaches:

1. the production of genetically modified species of microorganisms commonly used in food production and their use for production of enzymes mentioned above; or

2. the transfer of genes coding for these enzymes to transgenic plants and use the plants for production of mycotoxin degrading enzymes.

In staple food such as bread and bakery products in the flour sector, yeast and lactobacilli now play an important role. It thus stands to reason that the same microbes and enzymes are the first to have been considered for use as detoxifying or decontaminating agents. This type of biodegradation could therefore prove a useful strategy for partially overcoming the problem of some mycotoxins. Indeed, this already takes place in bread and in sourdough processes [24]; and OTA in food can also undergo biodegradation [25] and certain antagonistic yeast strains can substantially degrade OTA. This might offer new possibilities for reducing this mycotoxin in bread and bakery products and their raw materials [15]. The use of enzymes or engineered micro-organisms (provided that these are allowed by legislation) as processing aids in the bread and bakery sector would also prove beneficial. Genetic engineering technologies will improve the efficiency with which enzymes can be produced from these organisms, and will allow the production of engineered organisms which have the target genes. They will additionally increase the availability and bioavailability, and will improve the quality of the end product. 


\subsection{Inhibition of mycotoxins biosynthesis by lactic acid bacteria}

Several papers dealing with the inhibition of mycotoxin biosynthesis by LAB have focused on aflatoxins [26]. During cell lysis, it is possible that LAB releases molecules that potentially inhibit mould growth and therefore lead to a lower accumulation of their mycotoxins [27]. These "anti-mycotoxinogenic" metabolites could also be produced during LAB growth. Gourama [28], using a dialysis assay, demonstrated the occurrence of a metabolite that inhibits aflatoxin accumulation in Lactobacillus cell-free extracts. It was suggested that this inhibition of aflatoxin biosynthesis was not the result of a hydrogen peroxide production or a $\mathrm{pH}$ decrease [29]. These findings were consistent with those of Gourama, who suggested that inhibition of aflatoxin biosynthesis by Lactobacillus cell free supernatants was probably due to specific bacterial metabolites. Coallier-Ascah and Idziak [30] reported a significant reduction of aflatoxin biosynthesis by Lactobacillus cell free supernatants and suggested that this inhibition was related to a heat stable, low-molecular-weight inhibitory compound. Although Lactobacillus spp. were found to delay aflatoxin biosynthesis, other lactic strains such as L. lactis were found to stimulate aflatoxin accumulation [31].

\subsection{Decontamination of mycotoxins using microorganisms by binding or degradation}

Biological detoxification of mycotoxins works mainly via two major processes, sorption and enzymatic degradation, both of which can be achieved by biological systems. Recently a critical review on biological detoxification by Dalié et al. [32] summarized different and interesting aspects of the biological detoxification of mycotoxins. Microorganism detoxification can be performed in many different ways [33]:

1. the entire organism can be used as a starter culture, as in the fermentation of beer, wine and cider, or in lactic acid fermentation of vegetables, milk and meat;

2. the purified enzyme can be used in soluble or immobilized (biofilter) forms;

3. the gene encoding the enzymatic activity can be transferred and overexpressed in a heterologous system; interesting candidates for this application include yeasts, probiotics and plants.

\subsubsection{Binding by yeast and $L A B$}

Live microorganisms can absorb either by attaching the mycotoxin to their cell wall components or by active internalization and accumulation. Dead microorganisms too can absorb mycotoxins, and this phenomenon can be exploited in the creation of biofilters for fluid decontamination or probiotics (which have proven binding capacity) to bind and remove the mycotoxin from the intestine.

Yeast and LAB cells are known to bind different molecules such as killer toxins and metal ions on complex binding structures on the cell wall surface [34-36]. Yeast cell wall is known to bind sterols from the medium and the binding molecule was identified as the cell wall mannan [37]. It is confirmed that removal of mycotoxins is by adhesion to cell wall 
components rather than by covalent binding or by metabolism, as the dead cells do not lose their binding ability [38-41]. Reported literature indicates that mannan components of the cell wall play a major role in aflatoxin binding by S. cerevisiae. However, more kinetic studies with live and physico chemically modified intact $S$. cerevisiae cells are needed to assess the role of different components of cell wall in mycotoxin binding. Raju and Devegowda [40] have shown that mannans can also bind other mycotoxins such as ochratoxin A and T-2 toxin. Yiannikouris et al. $[42,43]$ mentioned the zearalenone binding to $\beta$-D-glucans and Freimund et al. [44] shows that modified yeast $\beta$-1,3-glucan showed excellent binding with T-2 toxins in addition to zearalenone mycotoxins. This indicates the possibilities of more than one target for mycotoxin binding on the cell wall. The fact that binding of ochratoxins is also enhanced when yeast cells are replaced with physically extracted cell walls [9] or heat treated cells and a very rapid nature of toxin removal from liquid medium [45] indicates the adsorption physical nature of ochratoxin binding also. A comprehensive study of key interactions between zearalenone and $\beta$-D-glucans, based on NMR and X-ray diffraction studies, was reported in reference [46]. Interestingly, $\beta-1,3-\mathrm{D}$-glucan chains favor a very stable intra-helical association with zearalenone, nicely stabilized by $\beta-1,6-\mathrm{D}$-glucans side chains (Figure 1) [47]. Both hydrogen bonds and van der Waals interactions were precisely identified in the complex and could thus be proposed as driving interactions to monitor the association between the two molecules. It appears that the carbohydrate components are common sites for binding, with different toxins having different binding sites.

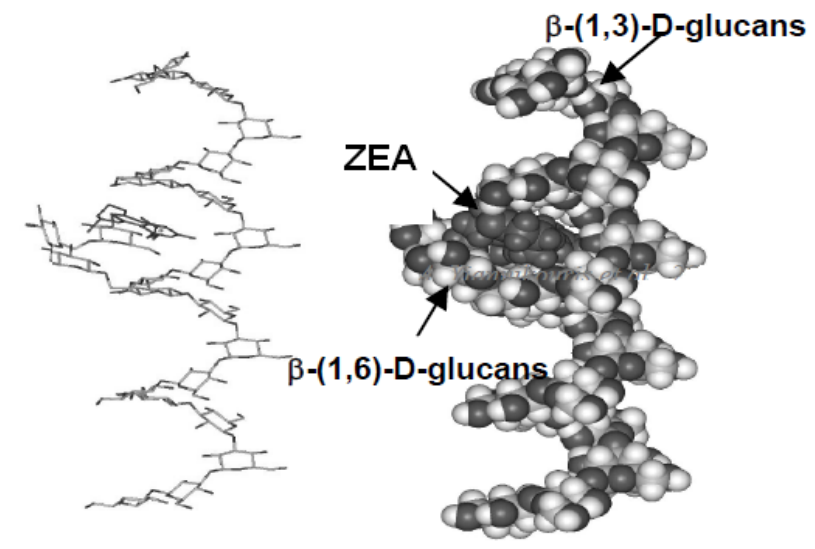

Figure 1. Computer-generated views of the energy-minimized structure of the docking of the most favorable conformation of zearalenone (ZEA) into the singlehelix of $\beta-1,3-\mathrm{D}$-glucan chain branched with $\beta$-1,6-D-glucan side chain [47]

Differences between strains of $\mathrm{LAB}$ with respect to aflatoxin binding indicates that binding ability is highly strain specific [48]. In some of the earlier studies, LAB are considered to be inefficient binders of aflatoxin $B_{1}[26,30]$. This may be due to the strains used in those studies were binding low amounts of aflatoxins occurs. Binding of aflatoxin $\mathrm{B}_{1}$ by viable or heat and acid treated bacteria depend on the initial concentration of the toxin [49]. Haskard 
et al. [50] studied the mechanism of binding of aflatoxins to L. rhamnosus using enzyme treatments and showed that binding is predominantly to carbohydrate and to some extent protein components in the cell wall. Treatment with urea considerably decreased the binding indicating the major role of hydrophobic interactions in binding. Electrostatic interactions are shown to play only a minor role as shown by treatments with $\mathrm{NaCl}$ and $\mathrm{CaCl}_{2}$. Binding of aflatoxin $\mathrm{B}_{1}$ was not affected by $\mathrm{pH}$, but had considerable effect on binding of aflatoxin $\mathrm{B}_{2 \mathrm{a}}$, indicating that different metabolites of the same mycotoxins with minor differences may show considerable differences with respect to binding mechanisms. Recently, it has been shown that peptidoglycan or the structures closely associated with peptidoglycan might be the most likely carbohydrate involved in aflatoxin $\mathrm{B}_{1}$ binding process [51]. Treatment with different specific proteases did not have any specific effect on the binding and a possible explanation for the effect seen earlier with pronase may be due to the release of other components associated with the proteins, thus affecting the binding process. Another mechanistic study [52] showed that binding of aflatoxins to the cell surface is considerably strong. Viable cells of L. rhamnosus strains LGG and LC105 retained 38 and $50 \%(\mathrm{w} / \mathrm{w})$ respectively of the bound toxins after repeated washings with water. However, non-viable (heat and acid treated) cells retained $66-71 \%(\mathrm{w} / \mathrm{w})$ of the toxin, indicating a higher stability of the complex. This higher binding of heat and acid treated cells was attributed to the better access of groups in the treated cells. Autoclaving and sonication did not release any detectable toxin from pre-washed cells indicating a high stability of the complex. Binding of aflatoxin $\mathrm{B}_{1}$ was found to be unaffected at a $\mathrm{pH}$ scale ranging from 2.5 to 8.5, suggesting the absence of a cation exchange mechanism and when the cell was treated with organic solvents, bound toxin was quickly extracted suggesting a major role of hydrophobic interaction in the binding [50]. Accessibility of bound aflatoxin to specific monoclonal antibody indicates the surface nature of binding [52].

\subsubsection{Degradation or biotransformation}

Another approach to the biological decontamination of mycotoxins involves their degradation or conversion into less toxic molecules by enzymes and selected microorganisms. Initial research in the field of mycotoxin biotransformation started 40 years ago. It has been demonstrated that some microorganisms produce enzymes that could alter the structure of mycotoxins and/or proteins that can conjugate these compounds, making them less active as pathogenic agents [53]. However, only few microorganisms have shown the capacity of degrading mycotoxins.

Karlovsky [20] has shown that the 12,13-epoxide ring of trichothecenes is responsible for their toxicity and that a reductive de-epoxidation caused by specific enzymes (deepoxidases) entails a significant loss of toxicity. For the elimination of the toxic effects of trichothecenes (deoxynivalenol or DON and T-2 toxin are the most well known members) Eubacterium BBSH 797 was isolated. The enzymes produced by this organism (for example epoxidases) play an important role by enabling the specific disruption of the toxic epoxy 
ring possessed by this group of mycotoxins (Figure 2). The destruction of deoxynivalenol may also be correlated to the action of oxidative enzymes that would catalyze the opening of the epoxide ring $[54,55]$.

Garvey et al. [56] have reported that enzymes known as trichothecene 3-O-acetyltransferases have the ability to modify DON by converting it to an acetylated derivative. These enzymes are also produced by fungi in the genus Fusarium, and are encoded by the genes TRI101 or TRI201 [57, 58]. The enzymatic modification involves the attachment of an acetyl group to the C-3 hydroxyl moiety of the trichothecene molecule [56], forming the derivative 3acetyldeoxynivalenol (3ADON) [59]. Expression of TRI101 has been shown to reduce the phytotoxic effects of trichothecenes in tobacco and rice [60, 61], and to decrease the inhibitory effects of trichothecenes on the growth of Saccharomyces pombe [59] and Chlamydomonas reinnardtii [62].

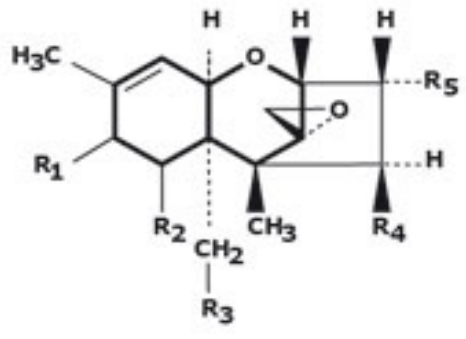

Trichothecenes

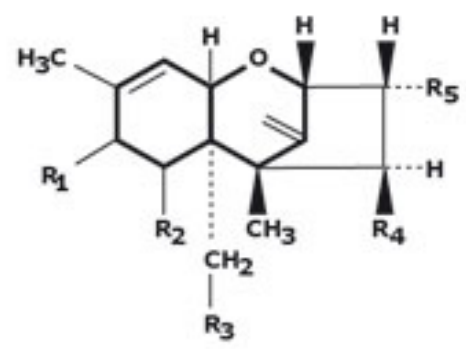

detoxified form

Figure 2. Biotransformation of trichothecenes into the detoxified forms (de-epoxy structures)

Very few scattered reports are available on the use of yeast and fungal strains for degradation zearalenone. S. cerevisiae strains were tested for their ability to degrade zearalenone in Sabouraud broth. Two strains were capable to degrade zearalenone totally, one strain decreased the mycotoxin concentration up to $25 \%$ and one strain up to $75 \%$ of the original amount. Later, the non-pathogenic yeast T. mycotoxinivorans MTV was isolated, described and patented for its ability to degrade zearalenone and ochratoxin A. For the elimination of zearalenone's negative effects it is vital that the lactone ring within the molecule is destroyed. This reaction is once again mediated by enzymes (e.g. esterases) (Figure 3). In doing so, zearalenone's resemblance with the sexual female hormone estradiol is lost and therefore impairment of the reproduction system is avoided.

In the case of ochratoxin A (OTA), two pathways may be are involved in OTA microbiological degradation [25]. First, OTA can be biodegraded through the hydrolysis of the amide bond that links the L- $\beta$-phenylalanine molecule to the ochratoxin alpha (OT $\alpha$ ) moiety (Figure 4). Since OT $\alpha$ and L- $\beta$-phenylalanine are virtually non-toxic, this mechanism can be considered to be a detoxification pathway. Second, a more hypothetical process involves OTA being degraded via the hydrolysis of the lactone ring. In this case, the final degradation product is an opened lactone form of OTA, which is of a similar toxicity to OTA 
when administered to rats. However, it is less toxic to mice and Bacillus brevis. Although this is hypothetical, it is likely to occur since microbiological lactonohydrolases, which undertake a similar transformation, are common.

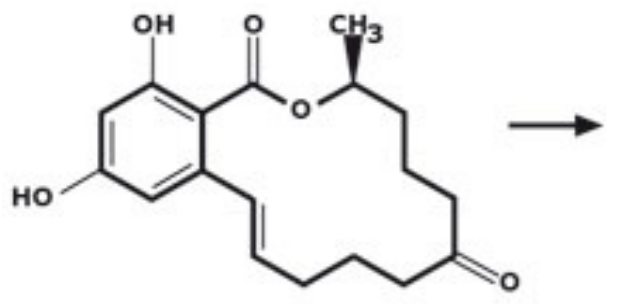

Zearalenone

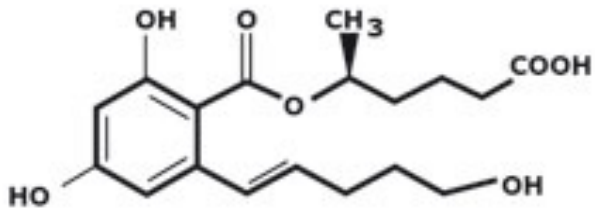

detoxified form

Figure 3. Biotransformation of zearalenone into a detoxified form (ZOM-1)

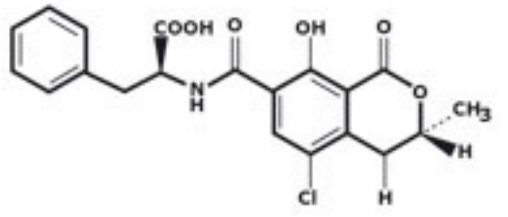

Ochratoxin A

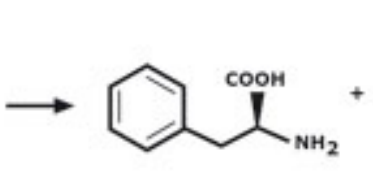

Phenylalanine<smiles>C[C@H]1Cc2c(Cl)cc(C(=O)O)c(O)c2C(=O)O1</smiles>

Ochratoxin a

Figure 4. Biotransformation of ochratoxin A into a detoxified form (ochratoxin alpha)

As a conclusion, mycotoxin risk management strategies must comprise several components. The elimination of adsorbable mycotoxins is possible to be done through adsorption; however, for the elimination of the toxicity of non-adsorbable mycotoxins, such as zearalenone, ochratoxins and trichothecenes biotransformation is crucial. Biotransformation, which is enabled by enzyme-producing microorganisms, allows the conversion of the toxic structure of mycotoxins into non-toxic, harmless metabolites.

\section{Possible approaches of microorganisms and enzymes for biodegradation of mycotoxins in food}

Mycotoxins frequently contaminate the food raw materials such as cereals, fruits, nuts, spices, milk and meat at various levels. Hence, for the food industry, it has always been an uphill task to keep the mycotoxin levels under check in the products, because mixing high contaminated commodities with low contaminated commodities to reach a level below the regulatory maximum limit is standard not allowed in the EU. Normally, low mycotoxin levels in the food are ensured by using mycotoxin-free, or raw materials with low levels of mycotoxins. In spite of these efforts, sporadically mycotoxin contamination is reported in the food products such as wine, beer, milk and milk products [63-65]. Strains of S. cerevisiae 
and $\mathrm{LAB}$ with high mycotoxin binding abilities can be used as part of the starter cultures in the fermentation of food and beverages, or heat treated cell walls or purified components of $S$. Cerevisiae and LAB can be used as additives in small quantities without compromising the characteristics of the final product. More importantly, S. cerevisiae and LAB are the major microorganisms involved in food fermentations in tropical countries with high levels of mycotoxin contamination in their foods. Strains of S. cerevisiae and LAB isolated from native fermented foods can be used as starter cultures with additional capacities to decontaminate mycotoxins in the food.

\subsection{Aflatoxins (AF)}

As the first mycotoxins being discovered were the aflatoxins (AF), also the first being targeted to be screened for microbial degradation were the aflatoxins. Several examples of the detoxification of the most common and important mycotoxins are reviewed. Almost 40 years ago, several species of microorganisms - including yeasts, moulds, bacteria, actinomycetes and algae - were screened for detoxification activity; based on this studies only one isolate was found, Flavobacterium auranotiacum, which significantly removed aflatoxin from a liquid medium.

Later AF decontamination during fermentation was reported in several cases. About $50 \%$ reduction in aflatoxins $\mathrm{B}_{1}$ and $\mathrm{G}_{1}\left(\mathrm{AFB}_{1}\right.$ and $\left.\mathrm{AFG}_{1}\right)$ has been reported during an early stage of miso fermentation. It was attributed to the degradation of the toxin by microorganisms. Significant losses of $\mathrm{AFB}_{1}$ and OTA were observed during beer brewing [66]. Detoxification of $\mathrm{AFB}_{1}$ occurred during the fermentation of milk by LAB and in dough fermentation during breadmaking. Govaris et al. [67] showed that aflatoxin $\mathrm{M}_{1}\left(\mathrm{AFM}_{1}\right)$ concentrations fell between 13 and $22 \%$ when cows' milk was fermented to produce yoghurt and by 16 and $34 \%$ after storage for yoghurts of $\mathrm{pH} 4.6$ and 4.0 respectively.

Digestive tract microorganisms are able to reduce mycotoxin levels not only by binding and removal but also by detoxification. Most data dealing with the effects of LAB on the accumulation of mycotoxins are related to aflatoxin-producing moulds. Wiseman and Marth [68] revealed the existence of an amenable relationship between L. lactis and A. parasiticus. When these authors added the spores of A. parasiticus to a 13-day-old culture of L. lactis, they observed the entire repression of AF production. When the fungal spore suspension and the LAB were inoculated simultaneously, an increase in AF production was observed. In contrast, Coallier-Ascah and Idziak [30] showed an inhibition of AF accumulation when both microorganisms were simultaneously cultivated in Lab-Lemco tryptone broth (LTB). Addition of glucose to the cultivation medium during the conidiation phase of the mould did not restore the production of AF. Several LAB have been found to be able to bind AFB 1 in vitro $[69,70]$, with an efficiency depending on the bacterial strain [71]. El-Nezami with coworkers [72] have evaluated the ability of five Lactobacillus strains (L. rhamnosus GG, L. rhamnosus LC705, L. acidophilus, L. gasseri, and L. casei) to bind aflatoxins in vitro and have shown that probiotic strains such as L. rhamnosus GG and L. rhamnosus LC705 were very effective for removing $\mathrm{AFB}_{1}$, removing as much as $80 \%(\mathrm{w} / \mathrm{w})$ of toxin immediately. Similar 
observations were also made with Flavobacterium aurantiacum (now known as Nocardia corynebacterioides), although there was a small amount of toxin which was degraded in live cells [73]. Later, many other strains of LAB were shown to bind AF in a strain specific manner [74]. L. rhamnosus strains GG and LC705 most effectively bound $\mathrm{AFB}_{1}$ than $\mathrm{AFB}_{2}$ and $\mathrm{AFG}_{1}$ [75]. In addition, the two strains showed similar $\mathrm{AFB}_{1}$ binding, even though they showed differences with respect to other metabolites. According to Coallier-Ascah and Idziak [30], the inhibition of $\mathrm{AF}$ accumulation was not related to a $\mathrm{pH}$ decrease but rather to the occurrence of a low-molecular-weight metabolite produced by the LAB at the beginning of its exponential phase of growth. Inhibition of aflatoxin production by other LAB belonging to the genus Lactobacillus was also reported [29]. It was assumed that this inhibition resulted from the production of a metabolite different from hydrogen peroxide or organic acid [28]. Haskard wich co-wokers [52] demonstrated that L. rhamnosus GG and L. rhamnosus LC705 were able to eliminate $\mathrm{AFB}_{1}$ from the culture medium by a physical process.

Several studies have suggested that the antimutagenic and anti-carcinogenic properties of probiotic bacteria can be attributed to their ability to non-covalently bind hazardous chemical compounds such as AF in the colon [70,76]. Both viable and non viable forms of the probiotic bacterium L. rhamnosus GG effectively removed aflatoxin $B_{1}$ from an aqueous solution [76]. Since metabolic activation is not necessary, binding can be attributed to weak, non-covalent, physical interactions, such as association to hydrophobic pockets on the bacterial surface [50].

\subsection{Ochratoxin A (OTA)}

The major OTA producers in food and feed products are considered to be $A$. alliaceus, $A$. carbonarius, A. ochraceus, A. steynii, A. westerdijkiae, P. nordicum and P. verrucosum [77]. These are mainly associated with agricultural crops preharvest, or in post harvest storage situations. Biological methods use microorganisms, which can decompose, transform or adsorb OTA to detoxify contaminated products or to avoid the toxic effects when mycotoxins are ingested. Several bacterial, yeast and filamentous fungal species are able to biodegrade OTA [25]. After success in clarifying the mechanism and degradation products of OTA, three directions in recent research may be observed (1) possibilities of bacterial and yeast degradation, (2) study of molds able to degrade this mycotoxin and (3) identification and isolation of enzymes taking part in the degradation process.

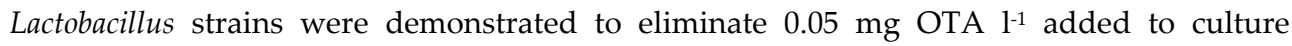
medium - in particular, L. bulgaricus, L. helveticus, L. acidophillus, eliminated up to $94 \%, 72 \%$ and $46 \%$, respectively, of OTA [78]; L. plantarum, L. brevis and L. sanfrancisco were reported to eliminate $54 \%, 50 \%$ and $37 \%$, respectively, of $0.3 \mathrm{mg} \mathrm{OTA}^{-1}$ after $24 \mathrm{~h}$ of incubation [79]. It is now generally accepted that OTA adsorption to the cells walls is the predominant mechanism involved in this OTA detoxification phenomenon by LAB. For example, adsorption effects were claimed by Turbic et al. [48], who found that heat and acid treated cells from two L. rhamnosus strains were more effective at removing OTA from phosphate buffer solutions than viable cells. The strains removed $36 \%$ to $76 \%$ in the buffer solution ( $\mathrm{pH}$ 
7.4) after $2 \mathrm{~h}$ at $37^{\circ} \mathrm{C}$. Similarly, Piotrowska and Zakowska [80] verified that L. acidophilus and $L$. rhamnosus caused OTA reductions of $70 \%$ and $87 \%$ of $1 \mathrm{mg}^{\text {OTA }} \mathrm{l}^{-1}$ after five days at $37^{\circ} \mathrm{C}$, and that significant levels of the OTA were present in the centrifuged bacteria cells. Other LAB (L. brevis, L. plantarum and L. sanfranciscencis) also produced smaller decreases on OTA (approximately 50\%). Del Prete et al. [81] tested 15 strains of oenological LAB in order to determine the in vitro capacity to remove OTA, and reported Oenococcus oeni as the most effective, with OTA reductions of $28 \%$. The involvement of cell-binding mechanisms was confirmed as (1) up to $57 \%$ of the OTA absorbed by the cells was recovered through methanol extraction from the bacteria pellets; (2) crude cell-free extracts were not able to degrade OTA; and (3) degradation products were not detected. Nevertheless, some authors consider that metabolism may also be involved. Fuchs et al. [82] confirmed that viable cells of $L$. acidophilus removed OTA more efficiently then unviable. L. acidophilus strain was able to decrease $\geq 95 \%$ the OTA in buffer solutions ( $\mathrm{pH}$ 5.0) containing 0.5 and $1 \mathrm{mg} \mathrm{OTA} \mathrm{l}^{-1}$ when incubated at $37^{\circ} \mathrm{C}$ for $4 \mathrm{~h}$. In addition, a detoxification effect was also demonstrated since pre-incubation of OTA with this strain reduced OTA toxicity to human derived liver cells (HepG2) [83]. Other L. acidophilus strains demonstrated only a moderate reduction in OTA contents suggesting that the effect was strain specific. In summary, some LAB adsorbs OTA by a strain specific cell-wall binding mechanism, although some undetected catabolism can also be involved. The detection of this OTA catabolism may only be possible with radiolabeled OTA. The potential of LAB as mycotoxin decontaminating agents has been studied in different fermentation processes and reviewed. The OTA content, its fate during wine-making and possibilities of its degradation have been intensively studied. Overviews concerning the presence and fate of this mycotoxin in grapes, wine and beer were published by Mateo et al. [84] and Varga and Kozakiewicz [85]. Although the decrease of OTA content in liquid phase during vinification process is observed by the majority of researchers, reports are controversial regarding the mechanism of OTA removal. Is it a result of malolactic fermentation due to the action of lactic acid bacteria [86], or is it adsorption to yeast cell walls [87]. Streptococcus salivarius subsp. thermophilus, Bifidobacterium bifidum, and yogurt bacteria have completely reduced OTA levels in milk samples containing 0.05 and $0.1 \mathrm{mg} \mathrm{l}^{-1}$; L. delbrueckii subsp. bulgaricus completely reduced OTA level in milk samples with $0.5 \mathrm{mg} \mathrm{l}^{-1}[88]$.

Several reports of OTA biodegradation by S. cerevisiae and other yeast have been published, and most of the effects detected and reported are from wall adsorption mechanisms. $S$. cerevisiae was claimed to biodegrade $41 \%$ of $0.3 \mathrm{mg}$ OTA $\mathrm{l}^{-1}$ after $24 \mathrm{~h}$ at $30{ }^{\circ} \mathrm{C}$, but details were not provided about the mechanism involved [73]. Similarly, Böhm et al. claimed that

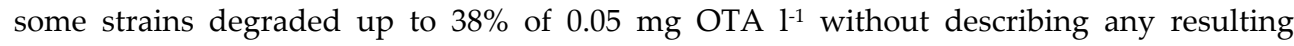
degradation metabolites [78]. On the other hand, the adsorption of OTA by oenological Saccharomyces strains was demonstrated by Bejaoui and co-authors, since they verified that heat and acid treated cells could bind significantly more OTA than viable ones [45]. Viable yeast bound up to $35 \%$ and $45 \%$ of the OTA, depending on the medium and strain, while heat and acid treated cells bound a maximum of $75 \%$. Additionally, yeast are reported to reduce OTA in alcoholic fermentation processes such as brewing or vinification. During 
wort fermentation, yeasts adsorbed a maximum of $21 \%$ of the added OTA [25]. Also, almost $30 \%$ of the added OTA was removed after extended contact with yeast biomass [89]. Cecchini and co-authors verified during vinification trials that up to $70 \%$ of OTA could be removed from wine and that a significant percentage of the removed OTA was found in yeast lees [90]. Adsorption assays that used several yeasts products or fractions were also carried out in order to understand and explain the mechanisms involved. Moruno and coauthors tested the capacity of active dried yeasts and yeast lees to remove OTA from wines and reported a reduction of approximately $70 \%$ when yeast lees were used [91]. The in vitro biosorption of OTA by vinasse containing yeast cell walls, purified yeast $\beta$-glucan and dried yeast cell wall fractions was studied [92]. Dried yeast cell wall fractions were reported to be the most efficient at adsorbing OTA. Several reports explained this phenomena by relating it to yeast $\beta$-D-glucans [93], glucomannans [94] and mannanoligosaccharide [95]. On the other hand, some studies emphasized the involvement of biodegradation mechanisms. Trichosporon, Rhodotorula and Cryptococcus demonstrated an ability to biodegrade OTA through the cleavage of the amide bond and releasing OT $\alpha$ [96]. In this study, the most

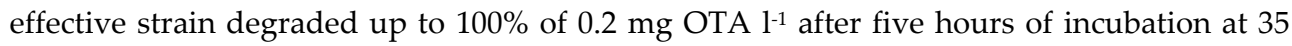
${ }^{\circ} \mathrm{C}$. This yeast was classified subsequently as the novel species Trichosporon mycotoxinivorans due to its excellent ability to detoxify OTA and ZEA [97]. However, a recent study recognized T. mycotoxinivorans as a novel human pathogen associated with cystic fibrosis and the death of a patient with histologically documented Trichosporon pneumonia: this obviously raises safety issues on its practical use [98]. A Phaffia rhodozyma strain was also able to degrade $90 \%$ of $7.5 \mathrm{mg}^{\circ T A ~} \mathrm{l}^{-1}$ after 15 days at $20{ }^{\circ} \mathrm{C}$ [99]. In this study, the conversion of OTA into OT $\alpha$ and the adsorption of OTA into viable and heat-treated cells was observed. More recently, Aureobasidium pullulans was reported to degrade OTA through the hydrolysis of the amide bond since OT $\alpha$ was detected [100]. The use as a biocontrol agent was also assessed as a reduction of OTA in grapes and wine was reported. However, the fungus appears to be involved in human disease and this issue needs to be resolved before more general use can be recommended [101].

Reports about the capacity of some filamentous fungi to biodegrade OTA can also be found. Some strains of Aspergillus fumigatus, A. japonicus, and A. niger have been reported to be able to degrade OTA to less toxic products such as ochratoxin R [102]. A. fumigatus, A. japonicus

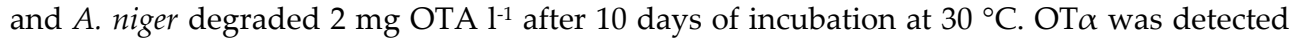
and further degradation into an unknown compound was observed. A. niger and other filamentous fungi have also shown to biodegrade OTA completely or partially, after growth in $1 \mathrm{mg}$ OTA $~^{-1}$ for six days at $25^{\circ} \mathrm{C}$ [103]. OT $\alpha$ was detected, particularly in the assays performed with $A$. niger and other black aspergilli. An unidentified biodegradation metabolite was observed in the assays carried out with $A$. ochraceus which did not produce OTA, and some A. wentii strains. Additionally, R. homothallicus, R. oryzae, $R$. stolonifer and other Rhizopus species degraded more than $95 \%$ of $7.5 \mathrm{mg}^{\text {OTA }} \mathrm{l}^{-1}$ after 16 days of incubation at $25{ }^{\circ} \mathrm{C}$ [18]. OT $\alpha$ was also detected in this study. Later, the excellent capacity of some black aspergilli to degrade OTA was confirmed: some A. carbonarius, A. japonicus, and A. niger 
strains degraded more than $80 \%$ of 2 mg OTA $^{-1}$ [104]. More recently, the capacity of Botrytis cinerea to degrade OTA was confirmed with reductions of $24.2 \%$ to $26.7 \%$ [105]. This provided an explanation for the low OTA contamination of noble rot and late-harvest wines. The white rot fungus Pleurotus ostreatus could degrade OTA (77\%) and OTB (97\%) when growth on contaminated barley by solid state fermentation, with OT $\alpha$ being detected from OTA biodegradation [106]. Rhizopus japonicus and Phanerochaete chrysosporium were also shown to biodegrade OTA to the lesser extents of $38 \%$ and $36 \%$, respectively.

Several enzymes may be involved in the microbiological degradation of OTA. However, little information is available and very few have been purified and characterized. The first reported protease able to hydrolyze OTA was carboxypeptidase A (CPA) from bovine pancreas [107]. Subsequently, a screening study which included several commercial hydrolases, verified that a crude lipase product from $A$. niger was able to hydrolyze OTA via the amide bond [108]. The enzyme was purified by anion exchange chromatography and was demonstrated to cleave OTA and p-nitrophenyl palmitate, a specific lipase substrate. Several proteolytic preparations were also studied, which were involved in the hydrolysis of OTA to OT $\alpha$. These included protease A from A. niger, pancreatin from porcine pancreas and to a lesser extent, prolyve PAC from A. niger [109]. Additionally, the production and purification of an $A$. niger cell-free crude enzyme preparation that demonstrated a significant capacity to cleave the amide bond of OTA was reported. The OTA-degrading enzyme involved was purified by anion exchange chromatography and characterized [110]. This enzyme showed higher OTA-degrading activity then CPA at $\mathrm{pH} 7.5$ and $37^{\circ} \mathrm{C}$, and was inhibited by EDTA, which is a specific inhibitor of metalloproteases. It was found that carboxypeptidase $\mathrm{Y}$ (CPY) from $S$. cerevisiae is also able to hydrolyze OTA with optimal activity at $\mathrm{pH} 5.6$ and $37^{\circ} \mathrm{C}$. However, the specific activity of CPY is very low as indicated by the OTA hydrolyzation reaction being very slow. Nevertheless, after five days of incubation, CPY converted $52 \%$ of the OTA present in the reaction assay into OT $\alpha$. This activity is sufficient to reduce significantly levels of OTA during wine or beer fermentation, since these processes take several days to complete. Hence, a biodegradation pathway is possible for S. cerevisiae in addition to the OTA adsorption phenomenon. It is necessary to consider that CPY is a vacuolar exopeptidase where OTA enters the yeast cells before it is catabolized. However, the $S$. cerevisiae wall-binding properties can make difficult OTA uptake. Although the results of these studies look very promising for reducing OTA contamination, studies on model systems do not guarantee the degradation of OTA in situ, using food. Further studies are needed to characterize the products of degradation and to investigate the activity of these microorganisms and enzymes in foods.

\subsection{Patulin (PAT)}

PAT contamination of apple and other fruit-based foods and beverages is an important food safety issue due to the high consumption of these commodities. PAT contamination is considered of greatest concern in apples and apple products; however, this mycotoxin has also been found in other fruits, such as pears, peaches, strawberries, blueberries, cherries, apricots and grapes as well as in cheese [8]. A number of studies have shown that PAT is 
generally unstable during fermentation so that products such as cider are usually free of PAT. It is likely that when PAT is reported in cider this is the result of the addition of apple juice to produce 'sweet cider'.

The initial studies concerning degradation of PAT by actively fermenting yeasts were reported by Stinson and co-authors [111]. However, authors were not able to chemically characterize the products of degradation. More recently, Moss and Long [112] reported that under fermentative conditions, the commercial yeast $S$. cerevisiae transformed PAT into ascladiol. They also showed that PAT was unstable in a study of the fate of [14C]-labelled PAT during the alcoholic fermentation of apple juice with $S$. cerevisiae. High-performance liquid chromatography (HPLC) analysis of the fermentations showed the appearance of two major metabolites, probably E- and Z-ascladiol. In a recent study [113] the ability of Gluconobacter oxydans to degrade PAT was investigated and the degradation products of this mycotoxin determined. More than $96 \%$ of PAT was degraded after $12 \mathrm{~h}$ treatment, due to change of chemical structure (opening of the pyran ring). The degradation product was confirmed to be ascladiol. The genus Gluconobacter, whose taxonomy is made up of five different species which have no health risk, are commonly used in food manufacturing [114]. Apple juice inoculated with this bacterium and incubated for 3 days still tasted like juice and was drinkable. However, keeping in mind the toxicity of ascladiol and eventual unsatisfactory organoleptic properties of alcoholic apple (fruit) juice (apple wine), the use of this bacterium at the industrial level needs additional investigation. In screenings for PAT detoxifying bacteria, a bacterium from fermented sausage has been isolated; it was identified as L. plantarum, and it significantly reduced PAT levels via an intracellular enzime. [8]

\subsection{Trichothecenes (type A and B) - Fusarium toxins such as DON and T-2/HT-2}

Several microorganisms have been found that can degrade deoxynivalenol (DON) and T-2 toxin. On the basis of morphological and phylogenetic studies, the degrader strain was classified as a bacterium belonging to the Agrobacterium Rhizobium group. L. rhamnosus strains LGG and LC 705 and Propionibacterium freudenreichii (PJ) were also shown to effectively bind some of the Fusarium toxins such as DON, 3-acetyldeoxynivalenol $(3 \mathrm{ADON})$, nivalenol (NIV), fusarenon-X (FUS-X), diacetoxyscirpenol (DAS), T-2 toxin, and HT-2 toxin [115]. The strains showed considerable differences in binding.

Studies on the effect of detoxification procedures for Fusarium mycotoxins by yeast fermentation have been mentioned by several authors. Using yeast in bread making from wheat contaminated with DON, levels of this mycotoxin were shown to be reduced. Samar et al. [116] found that fermentation reduced naturally occurring DON in Argentinean bread processing technology using a pilot scale plant. French bread and Vienna bread were prepared from wheat flour naturally contaminated with DON at $150 \mu \mathrm{g} \mathrm{kg}^{-1}$ in which dough was fermented at $30-50{ }^{\circ} \mathrm{C}$. The maximum reduction obtained in dough at $50{ }^{\circ} \mathrm{C}$ was $46 \%$ for the Vienna bread and $41 \%$ for French bread. This agreed with a study of Neira et al. [117], that showed a significant reduction of DON during the bread-making process. According to Garda et al. [118], alcoholic fermentation with S. cerevisiae can be considered as 
a promising method of detoxification of different levels of DON and T-2 toxin. It was found that the fermentation process of malt contaminated with DON and T-2 caused a decontamination of $53 \%$ for these mycotoxins, taking into account both the wort and the filtered sample. Yiannikouris and Jouany [119] noted that glucomannans extracted from the external cell walls of the yeast $S$. cerevisae are able to bind effectively aflatoxins and, to a lesser degree, ochratoxins and fusarium toxins. In contrast, the results mentioned by Hanschmann and Krieg [120], Bennet and Richard [121] and Schaafsma et al. [122] showed that DON was not destroyed by alcoholic fermentation and high levels in both the solid residue and the fermented liquid could be detected. Scott [123] mentioned that DON was stable after 7-9 days of wort fermentation by S. cerevisae. Böhm-Schraml et al. [124] demonstrated increasing DON levels within the first $20 \mathrm{~h}$ of fermentation of wort, which then subsequently decreased up to $100 \mathrm{~h}$. These results suggest that other procedures should be carried out on Fusarium-contaminated grains used as raw materials for fermentation and, also, that studies of the effect of fermentation on the decontamination process should be better evaluated.

Considerable amounts of other Fusarium mycotoxin zearalenone (ZEA) and its derivative $\alpha$ zearalenol were bound effectively (up to $55 \% \mathrm{w} / \mathrm{w}$ ) to the probiotic bacteria L. rhamnosus GG and L. rhamnosus LC705. Both heat-treated and acid-treated bacteria were capable of removing the toxins, indicating that binding, not metabolism is the mechanism by which the toxins are removed from the media [72]. A few other microbial activities that transform ZEA have been published but are protected by patents. Interactions between LAB and ZEA and its derivative, $\alpha$-zearalenol were also investigated. It was suggested that the yeast epihydroxylase might be involved. A significant proportion (38-48\%) of both toxins was trapped in the bacterial pellet and no degradation product of ZEA or $\alpha$-zearalenol was detected [72], leading to the conclusion that binding and not metabolism was the mechanism by which the toxins were removed from the media. Similar results were obtained with other mycotoxins including OTA $[82,125]$ and fumonisins $B_{1}\left(F_{1}\right)$ and $B_{2}$ $\left(\mathrm{FB}_{2}\right)$ [126]. Therefore, two specific processes such as binding and inhibition of biosynthesis may be involved in the interaction between LAB and the accumulation of some mycotoxins.

\subsection{Fumonisins}

Concerning the mechanisms of action involved in the removal of fumonisins by LAB, Niderkorn [126] suggested that peptidoglycans were the most plausible fumonisin binding sites. The quenching ability of LAB was increased when bacteria were killed using different physical and chemical treatments, while lysozyme and mutanolysin enzymes that target peptidoglycans partially inhibited it. It was also reported that tricarballylic acid chains found in fumonisin molecules played an important role in the binding process since hydrolysed fumonisin had less affinity for $\mathrm{LAB}$, and free amine group inactivation had no effect on the binding process. The same article attempted to explain the low affinity of $\mathrm{FB}_{1}$ using a molecular modelling approach. In fact, an additional hydroxyl group in FB 1 could form a hydrogen bond with one of the tricarballylic acid chains, resulting in a spatial configuration where the tricarballylic acid chain is less available to interact with bacterial 
peptodoglycans. Removal of fumonisins by LAB was ascribed to adhesion to cell wall components rather than covalent binding or metabolism, since the dead cells fully retained their binding ability. Peptidoglycans probably play a key rule in this binding process. Therefore, elucidating the differences between bacterial cell wall components of LAB strains might make it possible to select LAB species with the potential to act as biopreservative agents capable of reducing exposure from fumonisins that occur in foods.

\section{Detoxification of mycotoxins in animal feed}

Different mycotoxins are more commonly found in or associated with certain feedstuffs. Some develop in the growing crop due to its being susceptible to certain toxigenic fungi, while infection and toxin production by others is facilitated by the preservation and storage system used if insufficient care is taken to prevent this.

Most feeds are produced from crops at the farm and consumed by the animals some time later. However, some straight feeds and particularly mixed feeds are also produced and sold by feed mills. Feed raw materials are often divided into (1) cereals and by-products; (2) oilseed by-products; (3) leguminous seeds; (4) roots and tubers; (5) animal by-products; (6) green crops/pasture; (7) silages; (8) hays; (9) straws. They can be used straight, single or in combination in the feeding regime. Component types 1-5 are often combined and used as mixed feed and concentrates. The other raw material groups (6-9) are combined as roughage and mainly used for ruminants and horses.

\subsection{Ensiling}

Ensiling of mycotoxin-contaminated crops for detoxification has been proposed as an interesting and possible method for elimination or reduction of mycotoxins. Normal ensiling has, however, only rarely been studied for its mycotoxin degrading potential. A study by Rotter et al. [127] showed that ensiling of ochratoxin-contaminated barley could reduce the toxin by approximately $68 \%$. Yeasts in grass silage have been found to degrade patulin in silage inoculated with Paecilomyces sp. to induce patulin production [128]. Both bacteria and yeasts from maize silage have also been shown to be able to degrade fumonisins [129]. Stimulation of mycotoxin degradation by naturally occurring micro-organisms in silage or the addition of yeasts or bacteria with known mycotoxin degradation ability to silage may in the future become practical means to detoxify mycotoxins in certain crops.

\subsection{Yeasts as feed additives}

Yeasts have been fed to animals for more than a century and commercial yeast products are being specifically produced in commercial scale for animal feeding [39]. Hence, yeasts have immense potential as tools in tackling the problem of mycotoxins in animal feed.

In the poultry industry, S. cerevisiae has been used as general performance promoter in poultry feeds and has recently been shown to have beneficial effects against AFB 1 exposure $[39,130]$. There are many reports on use of physically separated yeast cell walls obtained 
from brewery as feed additive in poultry diet resulting in amelioration of toxic effects of aflatoxins [41]. When dried yeast and yeast cell walls were added to rat-ration along with $A F B_{1}$, a significant reduction in the toxicity was observed [38]. In an in vitro study with the cell wall material, there was a dose dependent binding of as much as $77 \%(\mathrm{w} / \mathrm{w})$ and modified mannan-oligosaccharides derived from the $S$. cerevisiae cell resulted in as much as $95 \%(\mathrm{w} / \mathrm{w})$ binding [131]. In addition, compound also showed considerably high binding to ZEN and $\mathrm{FB}_{1}$, but only little binding to DON. Esterified glucomannan was later shown to provide protection in broilers exposed to OTA and T-2 toxin in addition to aflatoxin [94] and reduced the toxic effects of Fusarium toxins in horses [132]. A later study also confirms the protective effects of yeast glucomannan on aflatoxicosis in broilers [133].

In a recent study, seven different trichothecene 3-O-acetyltransferases transformed into the yeast strain RW2802 were analyzed for their ability to modify DON into 3ADON during a series of feeding assays; conversion levels ranged from $50.5 \%$ to $100 \%$, depending on the source of the acetyltransferase [134].

\subsection{Impact of enzymes on alcohol fermentation of mycotoxin contaminated grains and safety of distiller's dried grains with solubles (DDGS)}

A valuable co-product of fuel ethanol production, known as distillers dried grains with solubles (DDGS), is increasingly being used as a feed source for domestic animals. DDGS contains high levels of protein, fiber, minerals and vitamins [135, 136]. An increase in the supply and demand for DDGS [137] is expected to coincide with the increased production of fuel ethanol in commercial plants [138], which rely on the sale of DDGS to turn a profit [139]. One of the challenges facing the fuel ethanol industry is the management of mycotoxins such as DON in DDGS.

The degradation of mycotoxins during alcohol fermentation for the production of ethanol has been investigated only in a few studies, but many papers have appeared on the fate of mycotoxins during the production of beer and wine. Bennett et al. used zearalenonecontaminated maize for ethanol production, but the toxin was not degraded and remained in the fermentation residues [140]. Mycotoxins can often be found in beer and wine, but they are partly degraded and partly transferred to beer, with part remaining in the draff during the fermentation process [141-144]. Studies on alcohol fermentation by S. cerevisiae using grains (barley, corn or wheat) contaminated with DON [122, 123, 145, 146] showed that DON was stable to the alcoholic fermentation process and not metabolised by Saccharomyces yeasts.The mycotoxin concentration remaining in the draff (DDGS) may be relatively high and so traditional alcohol fermentation is not a very effective means of detoxifiying feed material.

Mycotoxin-contaminated cereals may in the future be used more often in industrial ethanol production. Enhanced degradation of mycotoxins by eventual addition of microorganisms with mycotoxin-degradation ability is needed if the DDGS are to be utilized for animal feed.

The impact of $\beta$-xylanase on the fermentation of Fusarium contaminated wheat was studied in our lab [12]. It was found that Fusarium-contaminated wheat with a high concentration of 
DON (3.95 $\mathrm{mg} \mathrm{kg}^{-1}$ ) negatively affected the fermentation by S. cerevisiae process and reduced the ethanol concentration by $13.5 \%$ in the fermented wort (Figure 5). The explanation for the decrease in the ratio of fermentation by $S$. cerevisiae might be the inhibitory effect of high concentrations of Fusarium mycotoxins on yeast growth [147]. Whitehead and Flannigan [148] suggested that trichothecenes inhibit mitochondrial function, causing slower oxygen utilisation by the yeast resulting in a slower growth rate. In addition, damage by Fusarium could result in loss of sugars and other components which could affect the ethanol productivity [149].

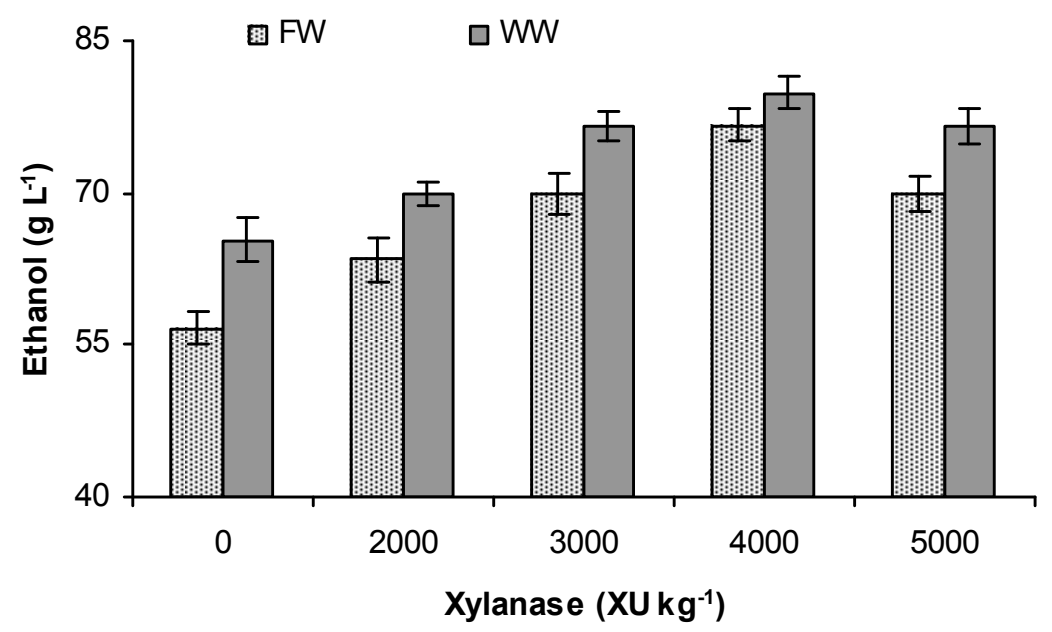

Figure 5. Effect of $T$. reesei xylanase on ethanol concentration in the fermented wort produced from Fusarium contaminated wheat (FW) and wholesome wheat (WW); 0 - sample prepared by using only amylolytic enzymes

The complex of amylolytic enzymes with xylanase from $T$. reesei, used for wort saccharification, increased the efficiency of the fermentation process of Fusariumcontaminated wheat: the ethanol concentration increased by $35.3 \%$. The addition of xylanase also improved the quality of bioethanol by decreasing the concentrations methanol, methyl acetate, isoamyl and isobutyl alcohols (Figure 6). The increase of the ethanol concentration could be influenced by synergetic action of the different side glycoside hydrolases, which renders the solubilisation and depolymerisation of non-starch polysaccharides to their monomeric constituent sugars and the higher concentration of hexoses in the medium. A higher activity of yeast enzymes and biomass formation are obtained, herewith fostering the carbohydrate metabolism to ethanol and carbon dioxide [150]. The formation of methanol and methyl acetate during the fermentation indicated that Fusarium-contaminated wheat was a pure growing medium for yeasts. Studies by Reinehr and Furlong demonstrated that unpredictable productions of methanol and higher alcohols could be obtained during the fermentation process of malt, depending on the presence of fungal contamination in cereals [151]. 
The results indicated that DON concentrations in the DDGS were significantly higher than in the starting material (Fusarium contaminated wheat). DON concentrations increased by a factor of 2.1-2.4 on a dry matter basis in DDGS in compare with starting wheat (Table 2). Increase in concentration of mycotoxins in DDGS is due to the reduction in total solid mass during fermentation, together with the loss of moisture during drying of the DDGS, and therefore a mass balance was used. The balance of mycotoxin contents showed the reduction of DON in the process. Traditional mash preparation and alcoholic fermentation by $S$. cerevisiae decreased the initial contamination by $26 \%$. By using the complex of amylolytic enzymes and T. reesei xylanase for mash saccharification, decontamination of DDGS was 31$41 \%$. The highest level of decontamination was obtained by a xylanase activity of $4000 \mathrm{XU}$ $\mathrm{kg}^{-1}$, and it was possible to decrease DON level in the DDGS by $15 \%$ in compare with the sample with only amylolytic enzymes used.
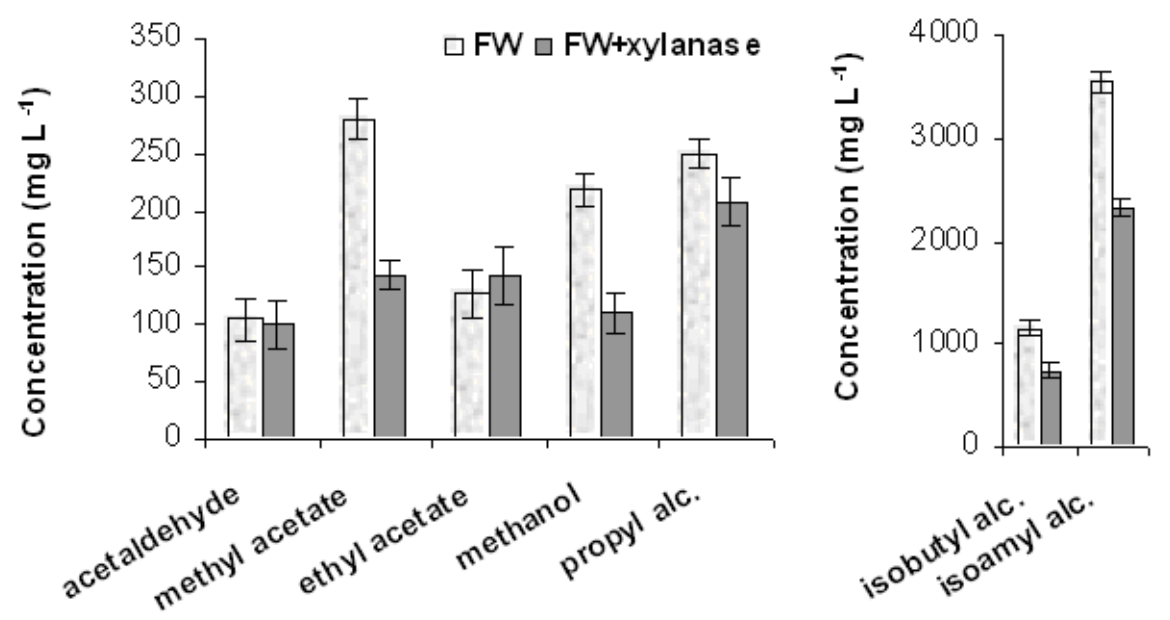

Figure 6. Effect of T. reesei xylanase on the concentrations of fusel oils and methanol in the distillates from Fusarium contaminated wheat (FW)

\begin{tabular}{|c|c|c|c|c|c|}
\hline \multirow[t]{2}{*}{ Sample } & \multirow{2}{*}{$\begin{array}{c}\text { Moisture } \\
\text { content (g } \\
\left.\mathrm{kg}^{-1}\right)\end{array}$} & \multirow{2}{*}{$\begin{array}{l}\text { Dry weight } \\
(\mathrm{kg})\end{array}$} & \multicolumn{2}{|c|}{$\begin{array}{l}\text { DON concentration, dry } \\
\text { matter } \\
\end{array}$} & \multirow{2}{*}{$\begin{array}{c}\text { DON } \\
\text { recovery } \\
(\%)\end{array}$} \\
\hline & & & Absolute (mg) & $\mathrm{mg} \mathrm{kg}^{-1}$ & \\
\hline Input wheat & $118 \pm 2$ & $0.882 \pm 0.002$ & $3.48 \pm 0.01$ & 3.95 & \\
\hline $\begin{array}{l}\text { DDGS, without } \\
\text { xylanase }\end{array}$ & $68 \pm 5$ & $0.266 \pm 0.005$ & $2.57 \pm 0.01$ & 9.66 & 74 \\
\hline DDGS, 2000 XU kg-1 & $82 \pm 9$ & $0.253 \pm 0.003$ & $2.41 \pm 0.01$ & 9.53 & 69 \\
\hline DDGS, 3000 XU kg-1 & $79 \pm 8$ & $0.246 \pm 0.006$ & $2.34 \pm 0.01$ & 9.51 & 67 \\
\hline DDGS, 4000 XU kg-1 & $74 \pm 7$ & $0.245 \pm 0.003$ & $2.05 \pm 0.01$ & 8.37 & 59 \\
\hline DDGS, 5000 XU kg-1 & $80 \pm 9$ & $0.245 \pm 0.005$ & $2.10 \pm 0.01$ & 8.57 & 60 \\
\hline
\end{tabular}

Table 2. DON assessment and mass balance on wheat and its bioethanol co-product DDGS 
The decrease in DON levels may have occurred due to absorbtion by yeast cells or extracellular metabolism resulting in protection from mycotoxin-induced toxicities [124]. According to Yiannikouris and Jouany [119], glucomannans from the external part of the cell wall of S. cerevisae are able to bind DON by $12.6 \%$. The potential effects of ethanol fermentation by yeasts on the decomposition of Fusarium mycotoxins (trichothecenes) were studied by Flesch and Voight-Scheuerman [152] during alcoholic fermentation of grape juice. Derivatives that did not contain epoxide groups were found, suggesting that a yeast epihydroxylase may have been present. It was also suggested that the yeast probably produced ligases and also a keto-enol tautomerase. It was established that a significant amount of mycotoxins (about 20\%) were taken up by yeast. With reference to our investigations, by using xylanase suplementation for saccharification of contaminated wheat the synthesis of yeast biomass could be increased, herewith fostering the absorbtion or biotransformation of mycotoxins and reduction of DON levels (up to $41 \%$ ) in DDGS. Therefore, saccharification using the complex of amylolytic enzymes with xylanase and alcoholic fermentation by $S$. cerevisiae can be considered as a promising method of DON detoxification.

Another approach to reduce DON in DDGS might be to add an exogenous trichothecene 3$O$-acetyltransferase preparation to the mash at the start of fermentation. In a recent study [153], Two Fusarium trichothecene 3-O-acetyltransferases (FgTRI101 and FfTRI201) were cloned and expressed in yeast (Saccharomyces cerevisiae) during a series of small-scale ethanol fermentations using barley (Hordeum vulgare). During the fermentation process, FgTRI101 converted $9.2 \%$ to $55.3 \%$ of the DON to $3 \mathrm{ADON}$, resulting in DDGS with reductions in DON and increases in $3 \mathrm{ADON}$. Employing yeast to express mycotoxin-detoxification genes represents a potential strategy to reduce mycotoxin levels in fuel ethanol co-products. However, a number of issues must be addressed before this process is commercialized. First, the composition of DDGS in future work using transformed yeast would need to be evaluated. Second, the use of a transgenic yeast strain for fuel ethanol production will need to be accepted by policy makers and ethanol production facilities in order to be implemented on a commercial scale.

\section{Conclusion and future concerns}

Prevention of mycotoxin formation is the best defence for protecting the consumer's health. However, prevention is not always possible, especially for those mycotoxins formed under field conditions. Introduction of further legislation for a wider range of mycotoxins in more food commodities means that there is a much greater need to determine how mycotoxins survive processing so that this can be taken into account when setting statutory or guideline limits. It is thus expected that there will be a trend towards further study of the fate of those mycotoxins that pose the greatest potential risk for humans. In some instances it may then be possible to introduce modifications to commercial processes that result in a significant reduction of mycotoxin content in the retail product. 
Contaminated crops condemned as food can otherwise be diverted for use as animal feed. Therefore, prevention and reduction of mycotoxin contamination during feed production will become more important. Mycotoxin-contaminated crops must be used in more cases for purposes other than direct food and feed and their utilization will be further investigated. Decontamination procedures will be further studied. Physical methods will be studied, but biological methods probably more so. Mycotoxin-contaminated cereals may in the future be used more often in industrial ethanol production. An enhanced degradation of mycotoxins by eventual addition of microorganisms or enzymes with mycotoxin-degradation ability is needed if the fermentation remains are to be utilized for animal feed.

In this chapter, we have tried to provide information on decontamination of various mycotoxins during fermentation procceses using bacteria, yeasts, fungi and enzymes. Based on the available reports, we can conclude that microorganisms are the main living organisms applicable for mycotoxin decontamination in foods. Results of various researchers showed that yeasts and bacterial strains had differences in decontamination of mycotoxins. For example, Kluyveromyces marxianus was sensitive to all trichothecene toxins, but this yeast was not inhibited by other mycotoxins, and B. brevis was sensitive to eight mycotoxins, including ZEA and OTA, but was not affected by high concentrations of trichothecene toxins. However, the results achieved in microbiological decontamination of mycotoxins until today may be treated as a first step in development of practical commercial technologies. Further intensive screening of mycotoxin-degrading microorganisms may lead to detection of efficient and applicable ones. Based on the available reports of mycotoxindegrading microorganisms in the digestive tract of animals, the activity of these microorganisms may be increased and they may be used in vivo for degradation of mycotoxins in food. With the application of molecular biology techniques, the potential mycotoxin degrading microbial strains can be engineered to significantly improve the quality and safety of foods from mycotoxins contamination to protect consumer's health.

\section{Author details}

Grazina Juodeikiene and Loreta Basinskiene

Department of Food Technology, Kaunas University of Technology, Kaunas, Lithuania

Elena Bartkiene and Paulius Matusevicius

Department of Food Safety and Quality, Lithuanian University of Health Sciences, Kaunas, Lithuania

\section{References}

[1] Reddy KRN, Salleh B, Saad B, Abbas HK, Abel CA, Sheir WT (2010) An overview of mycotoxin contamination in foods and its implications for human health. Toxin Rev. 29: 3-26. 
[2] Chassy BM (2010) Food safety risk and consumer health. New Biotechnol. 27(5): 534544.

[3] Wild CP (1996) Summary of data on aflatoxin exposure in West Africa. In: Cardwell KF, editor. Proceedings of the workshop on mycotoxins in food in Africa, November 6-10, 1995, Cotonou, Benin. Benin: International Institute of Tropical Agriculture. p. 26.

[4] Anonymous (2004) Outbreak of aflatoxin poisoning. Eastern and central provinces, Kenya, Januar-July 2004. Morb. Mortal Wkly. Rep. 53: 790-793.

[5] Gong Y, Hounsa A, Egal S, Turner PC, Sutcliffe AE, Hall AJ, Cardwell K, Wild CP (2004) Post weaning exposure to aflatoxin results in impaired child growth: A longitudinal study in Benin, West Africa. Environ. Health Perspect. 112: 1334-1338.

[6] Williams JH, Phillips TD, Jolly PE, Stiles JK, Jolly CM, Agarwal D (2004) Human aflatoxicosis in developing countries: A review of toxicology, exposure, potential health consequences, and interventions. Am. J. Clin. Nutr. 80: 1106-1122.

[7] Diaz DE, Hagler WM, Blackwelder JT, Eve JA, Hopkins BA, Andersen KL (2004) Aflatoxin binders II: Reduction of aflatoxin M1 in milk by sequestering agents of cows consuming aflatoxin in feed. Mycopathol.157: 233-241.

[8] Halász A, Lásztity R, Abonyi T, Bata A (2009) Decontamination of mycotoxincontaining food and feed by biodegradation. Food Rev. Int. 25(4): 284-298.

[9] Huwig A, Freimund S, Käppeli O, Dutler H (2001) Mycotoxin detoxication of animal feed by different adsorbents. Toxicol. Lett. 122: 179-188.

[10] Piva G, Galvano F, Pietri A, Piva A (1995) Detoxification methods of aflatoxins. A review. Nutr. Res. 15: 767-776.

[11] He J, Zhou T, Young JC, Boland GJ, Scott PM (2010) Chemical and biological transformations for detoxification of trichothecene mycotoxins in human and animal food chains: a review. Trends Food Sci. Technol. 21(2): 67-76.

[12] Juodeikiene G, Basinskiene L, Vidmantiene D, Makaravicius T, Bartkiene E (2012) Benefits of $\beta$-xylanase for wheat biomass conversion to bioethanol. J. Sci. Food Agr. 92(1): 84-91.

[13] Bata A, Lasztity R (1999) Detoxification of mycotoxin contaminated food and feed by microorganisms. Trends Food Sci. Technol. 10: 223-228.

[14] Reddy KRN, Reddy CS, Muralidharan K (2009) Potential of botanicals and biocontrol agents on growth and aflatoxin production by Aspergillus flavus infecting rice grains. Food Control. 20: 173-178.

[15] Patharajan S, Reddy KRN, Karthikeyan V, Spadaro D, Gullino ML, Garibaldi A (2011) Potential of yeast antagonists on in vitro biodegradation of ochratoxin A. Food Control. 22: 290-296.

[16] Styriak I, Concova E (2002) Microbial binding and biodegradation of mycotoxins. Vet. Human Toxicol. 44: 358-361.

[17] La Penna M, Nesci A, Etcheverry M (2004) In vitro studies on the potential for biological control on Aspergillus section Flavi by Kluyveromyces spp. Lett. Appl. Microbiol. 38: 257264. 
[18] Varga J, Péteri Z, Tábori K, Téren J, Vagvolgyi C (2005) Degradation of ochratoxin-A and other mycotoxins by Rhizopus isolates. Int. J. Food Microbiol. 99: 321-328.

[19] Pereira P, Nesci A, Castillo C, Etcheverry M (2010) Impact of bacterial biological control agents on fumonisin B1 content and Fusarium verticillioides infection of field-grown maize. Biol. Control. 53: 258-266.

[20] Karlovsky P (1999) Biological detoxification of fungal toxins and its use in plant breeding, feed and food production. Nat. Toxins. 7: 1-23.

[21] Shetty PH, Jespersen L (2006) Saccharomyces cerevisiae and lactic acid bacteria as potential mycotoxin decontamination agents. Trends Food Sci. Technol. 17: 48-55.

[22] Jespersen L (2003) Occurrence and taxonomic characteristics of strains of Saccharomyces cerevisiae predominant in African fermented foods and beverages. FEMS Yeast Res. 3: 191-200.

[23] Celyk K, Denly M, Savas T (2003) Reduction of toxic effects of aflatoxin by using baker yeast (Saccharomyces cerevisiae) in growing broiler chicken diets. Rev. Bras. Zootecn. 32: 615-619.

[24] Bartkiene E, Juodeikiene G, Vidmantiene D (2008) Evaluation of deoxynivalenol in wheat by acoustic method and impact of starter on its concentration during wheat bread baking process. Food Chem. Technol. 42(1): 5-12.

[25] Abrunhosa L, Paterson RRM, Venâncio A (2010) Biodegradation of ochratoxin A for food and feed decontamination. Toxins. 2: 1078-1099.

[26] Thyagaraja N, Hosono A (1994) Binding properties of lactic acid bacteria from 'Idly' towards food-borne mutagens. Food Chem. Toxicol. 32: 805-809.

[27] Gourama H, Bullerman LB (1995) Inhibition of growth and aflatoxin production of Aspergillus flavus by Lactobacillus species. J. Food Protect. 58: 1249-1256.

[28] Gourama H (1991) Growth and aflatoxin production of Aspergillus flavus in the presence Lactobacillus species. Ph.D. thesis, University of Nebraska-Lincoln.

[29] Karunaratne A, Wezenberg E, Bullerman LB (1990) Inhibition of mold growth and aflatoxin production by Lactobacillus spp. J. Food Protect. 53: 230-236.

[30] Coallier-Ascah J, Idziak E (1985) Interaction between Streptococcus lactis and Aspergillus flavus on production of aflatoxin. Appl. Environ. Microb. 49: 163-167.

[31] Luchese RH, Harrigan WF (1990) Growth of and aflatoxin production by Aspergillus parasiticus when in the presence of either Lactococcus lactis or lactic acid and at different initial pH values. J. Appl. Bacteriol. 69: 512-519.

[32] Dalié DKD, Deschamps AM, Richard-Forget F (2009) A review: Lactic acid bacteria Potential for control of mould growth and mycotoxins. Food Control. 21(4): 370-380.

[33] Moreno-Aribas MV, Polo MC (2010) Wine Chemistry and Biochemistry. In: Magan N, Olsen $\mathrm{M}$, editors.Mycotoxins in food Detection and control: Biological decontamination of mycotoxins. New York: Springer, Woodhead Publishing Ltd and CRC Press: LLC. pp. 2006-2211. 
[34] Brady D, Stoll A D, Strake L, Dunkan J R (1994) Chemical and enzymatic extraction of heavy metal binding polymera from isolated cell walls of Saccharomyces cerevisiae. Biotechnol. Bioeng. 44: 297-302.

[35] Bolognani F, Rumney CJ, Rowland IR (1997) Influence of carcinogen binding by lactic acid-producing bacteria on tissue distribution and in vitro mutagenecity of dietary carcinogens. Food Chem. Toxicol. 35: 535-545.

[36] Santos A, Marquina D, Leal JA, Peinado JM (2000) (1-6)- $\beta$-D-glucan as cell wall receptor for Pichia membranifaciens killer toxin. Appl. Environ. Microb. 66: 1809-1813.

[37] Thompson ED, Knights BA, Parks LW (1973) Identification and properties of a sterolbinding polysaccharide isolated from Saccharomyces cerevisiae. Biochim. Biophys. Acta. 304: 132-141.

[38] Baptista AS, Horii J, Calori-Domingues MA, da Gloria EM, Salgado JM, Vizioli MR (2004) The capacity of mannooligosaccharides thermolysed yeast and active yeast to attenuate aflatoxicosis.World J. Microb. Biot. 20: 475-481.

[39] Celyk K, Denly M, Savas T (2003) Reduction of toxic effects of aflatoxin by using baker yeast (Saccharomyces cerevisiae) in growing broiler chicken diets. Rev. Bras. Zootecn. 32: 615-619.

[40] Raju MVLN, Devegowda G (2000) Influence of esterifiedglucomannan on performance and organ morphology, serum biochemistry and haematology in broilers exposed to individual and combined mycotoxicosis (aflatoxin, ochratoxin and T-2 toxin). Brit. Poultry Sci. 41: 640-650.

[41] Santin E, Paulilo AC, Maiorka A, Nakaghi LSO, Macan M, de Silva AVF (2003) Evaluation of the efficiency of Saccharomyces cerevisiae cell wall to ameliorate the toxic effects of aflatoxin in broilers. Int. J. Poultry Sci. 2: 241-344.

[42] Yiannikouris A, François J, Poughon L, Dussap CG, Bertin G, Jeminet G, Jouany JP (2004) Adsorption of zearalenone by beta-D-glucans in the Saccharomyces cerevisiae cell wall. J. Food Prot. 67: 1195-1200.

[43] Yiannikouris A, François J, Poughon L, Dussap CG, Bertin G, Jeminet G, Jouany JP (2004) Alkali extraction of beta-D-glucans from Saccharomyces cerevisiae cell wall and study of their adsorptive properties toward zearalenone. J. Agric. Food Chem. 52: 36663673 .

[44] Freimund S, Sauter M, Rys P (2003) Efficient adsorption of mycotoxins zearalenone and T-2 toxin on a modified yeast glucan. J. Environ. Sci. Health B. 38(3): 243-255.

[45] Bejaouii H, Mathieu F, Taillandier P, Lebrihi A (2004) Ochratoxin A removal in synthetic and natural grape juices by selected oenological Saccharomyces strains. J. Appl. Microbiol. 97: 1038-1044.

[46] Yiannikouris A, Andre G, Buleon A, Jeminet G, Canet I, François J, Bertin G, Jouany JP (2004) Comprehensive conformational study of key interactions involved in zearalenone complexation with beta-D-glucans. Biomacromolecules. 5: 2176-2185. 
[47] Jouany JP,. Yiannikouris A, Bertin G (2005) The chemical bonds between mycotoxins and cell wall components of Sacharomyces cerevisiae have been identified. Arch. Zootech. 8: 26-50.

[48] Turbic A, Ahokas JT, Haskard CA (2002) Selective in vitro binding of dietary mutagens, individually or in combination, by lactic acid bacteria. Food Addit. Contam. 19: 144-152.

[49] Haskard CA, El-Nezami HS, Peltonen KD, Salminen S, Ahokas JT (1998). Sequestration of aflatoxin B1 by probiotic strains: Binding capacity and localization. Rev. Med. Vet.Toulouse. 149: 571.

[50] Haskard CA, Binnion C, Ahokas J (2000) Factors affecting the sequestration of aflatoxin by Lactobacillus rhamnosus strain GG. Chem-Biol. Interact. 128: 39-49.

[51] Lahtinen SJ, Haskard CA, Ouwehandz AC, Salminenz SJ, Ahokasy JT (2004) Binding of aflatoxin B1 to cell wall components of Lactobacillus rhamnosus strain GG. Food Addit. Contam. 21: 158-164.

[52] Haskard, C. A., El-Nezami, H. S., Kankaanpaa, P. E., Salminen, S.,\& Ahokas, J. T. (2001). Surface binding of alfatoxin B1 by lactic acid bacteria. Appl. Environ. Microb. 67: 30863091.

[53] Westby A, Reilly A, Bainbridge Z (1997) Review of the effect of fermentationon naturally occurring toxins. Food Control. 8(5/6): 329-339.

[54] Sweeney MJ, Dobson ADW (1998) Mycotoxin prodution by Aspergillus, Fusarium and Penicillium species. Int. J. Food Microbiol. 43: 141-158.

[55] Moss MO, Thrane U (2004) Fusarium taxonomy with relation to trichothecene formation. Toxicol. Lett. 153: 23-28.

[56] Garvey GS, McCormick SP, Rayment I (2008) Structural and functional characterization of the TRI101 trichothecene 3-O-acetyltransferase from Fusarium sporotrichioides and Fusarium graminearum: kinetic insights to combating Fusarium head blight. J. Biol. Chem. 283: 1660-1669.

[57] Kimura M, Tokai T, Matsumoto G, Fujimura M, Hamamoto H, Yoneyama K, Shibata T, Yamaguchi I (2003) Trichothecene nonproducer Gibberella species have both functional and nonfunctional 3-O-acetyltransferase genes. Genetics. 163: 677-684.

[58] Khatibi PA, Newmister SA, Rayment I, McCormick SP, Alexander NJ, Schmale DG (2011) Bioprospecting for trichothecene 3-O-acetyltransferases in the fungal genus fusarium yields functional enzymes with different abilities to modify the mycotoxin deoxynivalenol. Appl. Environ. Microbiol. 77: 1162-1170.

[59] Kimura M, Kaneko I, Komiyama M, Takatsuki A, Koshino H, Yoneyama K, Yamaguchi I (1998) Trichothecene 3-O-acetyltransferase protects both the producing organism and transformed yeast from related mycotoxins. Cloning and characterization of Tri101. J. Biol. Chem. 273: 1654-1661.

[60] Muhitch MJ, McCormick SP, Alexander NJ, Hohn TM (2000) Transgenic expression of the TRI101 or PDR5 gene increases resistance of tobacco to the phytotoxic effects of the trichothecene 4,15-diacetoxyscirpenol. Plant. Sci. 157: 201-207. 
[61] Ohsato S, Ochiai-Fukuda T, Nishiuchi T, Takahashi-Ando N, Koizumi S, Hamamoto H, Kudo T, Yamaguchi I, Kimura M (2007) Transgenic rice plants expressing trichothecene 3-O-acetyltransferase show resistance to the Fusarium phytotoxin deoxynivalenol. Plant. Cell. Rep. 26: 531-538.

[62] Alexander NJ, McCormick SP, Ziegenhorn SL (1999) Phytotoxicity of selected trichothecenes using Chlamydomonas reinhardtii as a model mystem. Natural Toxins. 265269.

[63] Blesa J, Soriano JM, Molto JC, Manes J (2004) Concentration of ochratoxin A in wines from supermarkets and stores of Valencian Community (Spain). J. Chromatogr. A. 1054: 397-401.

[64] Elgerbi AM, Aidoo KE, Candlish AA, Tester RF (2004) Occurrence of aflatoxin M1 in randomly selected North African milk and cheese samples. Food Addit. Contam. 21: 592-597.

[65] Odhav B, Naicker V (2002) Mycotoxins in South African traditionally brewed beers. Food Addit. Contam. 19: 55-61.

[66] Chu FS, Chang CC, Ashoor SH, Prentice N (1975) Stability of aflatoxin B, and ochratoxin A in brewing. Appl. Microbiol. 29: 313-316.

[67] Govaris A, Roussi V, Koidis PA, Botsoglou NA (2002) Distribution and stability of aflatoxin M1 during production and storage of yoghurt. Food Addit. Contam. 19: 10431050.

[68] Wiseman DW, Marth EH (1981) Growth and aflatoxin production by Aspergillus parasiticus when in the presence of Streptococcus lactis. Mycopathologia. 73: 49-56.

[69] Kankaanpää P, Tuomola E, El-Nezami H, Ahokas J, Salminen SJ (2000) Binding of aflatoxin B1 alters the adhesion properties of Lactobacillus rhamnosus strain GG in Caco-2 model. J. Food Protect. 63: 412-414.

[70] Gratz S, Mykkänen H, Ouwehand AC, Juvonen R, Salminen S, El-Nezami HS (2004) Intestinal mucus alters the ability of probiotic bacteria to bind aflatoxin B1 in vitro. Appl. Environ. Microb. 70: 6306-6308.

[71] Shah N, Wu X (1999) Aflatoxin B1 binding abilities of probiotic bacteria. Biosci. Microflora. 18: 43-48.

[72] El-Nezami HS, Polychronaki N, Salminen S, Mykkänen H (2002) Binding rather metabolism may explain the interaction of two food-grade Lactobacillus strains with zearalenone and its derivative $\alpha$-zearalenol. Appl. Environ. Microb. 68: 3545-3549.

[73] Line JE, Brackett RE (1995) Role of toxin concentration and second carbon source in microbial transformation of aflatoxin B1 by Flavobacterium aurantiacum. J. Food Protect. 58: 1042-1044.

[74] Peltonen K, El-Nezami H, Haskard C, Ahokas J, Salminen S (2001) Aflatoxin B1 binding by dairy strains of lactic acid bacteria and bifidobacteria. J. Dairy Sci. 84: 2152-2156.

[75] El-Nezami H, Haskard C, Salminen E, Mykkanen H, Ahokas J, Salminen S (2002) Lactic acid bacteria and bifidobacteria can reduce dietary exposure to aflatoxins. Brit. J. Nutr. 88: 119-121. 
[76] El-Nezami H, Kankaanpää P, Salminen S, Ahokas J (1998) Physicochemical alterations enhance the ability of dairy strains of lactic acid bacteria to remove aflatoxin from contaminated media. J. Food Protect. 61: 466-468.

[77] Frisvad JC, Thrane U, Samson RA, Pitt JI (2006) Important mycotoxins and the fungi which produce them. Adv. Exp. Med. Biol. 571:3-31.

[78] Böhm J, Grajewski J, Asperger H, Rabus B, Razzazi E (2000) Study on biodegradation of some trichothecenes (NIV, DON, DAS, T-2) and ochratoxin A by use of probiotic microorganisms. Mycot. Res. 16: 70-74.

[79] Piotrowska M, Zakowska Z (2000) The biodegradation of ochratoxin A in food products by lactic acid bacteria and baker's yeast. In: Bielecki S, Tramper J, Polak J, editors. Progress in Biotechnology (Food Biotechnology). Vol. 17. Amsterdam: Elsevier. pp. 307310.

[80] Piotrowska M, Zakowska Z (2005) The elimination of ochratoxin A by lactic acid bacteria strains. Pol. J. Microbiol. 54: 279-286.

[81] Del Prete V, Rodriguez H, Carrascosa AV, Rivas BDL, Garcia-Moruno E, Munoz R (2007) In vitro removal of ochratoxin A by wine lactic acid bacteria. J. Food Protect. 70: 2155-2160.

[82] Fuchs S, Sontag G, Stidl R, Ehrlich V, Kundi M, Knasmuller S (2008) Detoxification of patulin and ochratoxin A, two abundant mycotoxins, by lactic acid bacteria. Food Chem. Toxicol. 46: 1398-1407.

[83] Shetty PH, Jespersen L (2006) Saccharomyces cerevisiae and lactic acid bacteria as potential mycotoxin decontaminating agents. Trends Food Sci. Techn. 17: 48-55.

[84] Mateo R, Medina A, Mateo EM, Mateo F, Jimenez M (2007) An overview of ochratoxin $\mathrm{A}$ in beer and wine. Int. J. Food Microbiol. 119 (1-2): 79-83.

[85] Varga J, Kozakiewicz Z (2006) Ochratoxin-A in grapes and grape-derived products. Trends Food Sci. Techn. 1: 72-81.

[86] Kozakiewicz Z, Battilani P, Cabanes I, Venancio A, Mule G, Tjamos E (2003) Making wine safer. In: van Egmond $H$, van Osenbruggen T, Lopez Garcia R, Visconti A, editors. Meeting the Mycotoxin Menace. Wageningen: Wageningen Academic Publisher. pp.131-140.

[87] Binder EM, Heidler D, Schatzmayr G, Thimm N, Fuchs E, Schuh M, Krska R, Binder J (2000) Microbial detoxification of mycotoxins in animal feed. In: De Koe WJ, Samson RA, Van Egmond HP, Gilbert J, Sabino M, editors. Mycotoxins and Phytotoxins in Perspective at the Turn of the Millenium. Proceedings of the 10-th International IUPAC Symposium on Mycotoxins and Phytotoxins, Garuja, Brazil, May 20-25. IUPAC. pp. 271-277.

[88] Sÿkrinjar M, Rašić JL, Stojičić V (1996) Lowering of ochratoxin A level in milk by yoghurt bacteria and bifidobacteria. Folia Microbiol. 1: 26-28.

[89] Bizaj E, Mavri J, Cus F, Raspor A (2009) Removal of ochratoxin A in Saccharomyces cerevisiae liquid cultures. S. Afr. J. Enol. Vitic. 30: 151-155. 
[90] Cecchini F, Morassut M, Garcia Moruno E, Di Stefano R (2006) Influence of yeast strain on ochratoxin A content during fermentation of white and red must. Food Microbiol. 23: 411-417.

[91] Moruno EG, Sanlorenzo C, Boccaccino B, Di Stefano R (2005) Treatment with yeast to reduce the concentration of ochratoxin A in red wine. Am. J. Enol. Vitic. 56: 73-76.

[92] Ringot D, Lerzy B, Bonhoure JP, Auclair E, Oriol E, Larondelle Y (2005) Effect of temperature on in vitro ochratoxin A biosorption onto yeast cell wall derivatives. Process Biochem. 40: 3008-3016.

[93] Yiannikouris A, Andre G, Poughon L, Francois J, Dussap CG, Jeminet G, Bertin G, Jouany JP (2006) Chemical and conformational study of the interactions involved in mycotoxin complexation with $\beta$-D-glucans. Biomacromolecules. 7: 1147-1155.

[94] Raju MVLN, Devegowda G (2002) Esterified-glucomannan in broiler chicken dietscontaminated with aflatoxin, ochratoxin and T-2 toxin: Evaluation of its binding ability (in vitro) and efficacy as immunomodulator. Asian Australas. J. Anim. Sci. 15: 10511056.

[95] Oguz H, Parlat SS (2004) Effects of dietary mannanoligosaccharide on performance of Japanese quail affected by aflatoxicosis. S. Afr. J. Anim. Sci. 34: 144-148.

[96] Schatzmayr G, Heidler D, Fuchs E, Mohnl M, Täubel M, Loibner AP, Braun R, Binder EM (2003) Investigation of different yeast strains for the detoxification of ochratoxin A. Mycot. Res. 19: 124-128.

[97] Molnar O, Schatzmayr G, Fuchs E, Prillinger H (2004) Trichosporon mycotoxinivorans sp nov., a new yeast species useful in biological detoxification of various mycotoxins. Syst. Appl. Microbiol. 27: 661-671.

[98] Hickey PW, Sutton DA, Fothergill AW, Rinaldi MG, Wickes BL, Schmidt HJ, Walsh TJ (2009) Trichosporon mycotoxinivorans: A novel respiratory pathogen in patients with cystic fibrosis. J. Clin. Microbiol. 47: 3091-3097.

[99] Peteri Z, Teren J, Vagvolgyi C, Varga J (2007) Ochratoxin degradation and adsorption caused by astaxanthin-producing yeasts. Food Microbiol. 24: 205-210.

[100] de Felice DV, Solfrizzo M, De Curtis F, Lima G, Visconti A, Castoria R (2008) Strains of Aureobasidium pullulans can lower ochratoxin A contamination in wine grapes. Phytopathology. 98: 1261-1270.

[101] Hawkes M, Rennie R, Sand C, Vaudry W (2005) Aureobasidium pullulans infection: Fungemia in an infant and a review of human cases. Diagn. Microbiol. Infect. Dis. 51: 209-213.

[102] Varga J, Rigó K, Téren J (2000) Degradation of ochratoxin A by Aspergillus species. Int. J. Food Microbiol. 59: 1-7.

[103] Abrunhosa L, Serra R, Venâncio A (2002) Biodegradation of ochratoxin A by fungi isolated from grapes. J. Agric. Food Chem. 50: 7493-7496.

[104] Bejaoui H, Mathieu F, Taillandier P, Lebrihi A (2006) Biodegradation of ochratoxin A by Aspergillus section Nigri species isolated from French grapes: A potential means of 
ochratoxin A decontamination in grape juices and musts. FEMS Microbiol. Lett. 255: 203-208.

[105] Valero A, Sanchis V, Ramos AJ, Marin S (2008) Brief in vitro study on Botrytis cinerea and Aspergillus carbonarius regarding growth and ochratoxin A. Lett. Appl. Microbiol. 47: 327-332.

[106] Engelhardt G (2002) Degradation of ochratoxin A and B by the white rot fungus Pleurotus ostreatus. Mycot. Res. 18: 37-43.

[107] Pitout MJ (1969) The hydrolysis of ochratoxin A by some proteolytic enzymes. Biochem. Pharmacol. 18: 485-491.

[108] Stander MA, Bornscheuer UT, Henke E, Steyn PS (2000) Screening of commercial hydrolases for the degradation of ochratoxin A. J. Agric. Food Chem. 48: 5736-5739.

[109] Abrunhosa L, Santos L, Venâncio A (2006) Degradation of ochratoxin A by proteases and by a crude enzyme of Aspergillus niger. Food Biotechnol. 20: 231-242.

[110] Abrunhosa L, Venâncio A (2007) Isolation and purification of an enzyme hydrolyzing ochratoxin A from Aspergillus niger. Biotechnol. Lett. 29: 1909-1914.

[111] Stinson EE, Osman SF, Bills DD (2006) Water soluble products from patulin during alcoholic fermentation of apple juice. J. Food Sci. 44(3): 788-789.

[112] Moss MO, Long MT (2002) Fate of patulin in the presence of the yeast Saccharomyces cerevisiae. Food Addit. Contam. 19: 387-399.

[113] Richelli A, Baruzzi F, Solfrizzo M, Morea M, Fanizzi FP (2007) Biotransformation of patulin by Gluconobacter oxydans. Appl. Environ. Microb. 73: 785-792.

[114] Tanasupawat S, Thawai C, Yukphan P, Moonmangmee D, Itoh T, Adachi O, Yamada Y (2004) Gluconobacter thailandicus sp. nov., an acetic acid bacterium in the alpfaproteobacteria. J. Gen. Appl. Microb. 50, 159-167.

[115] El-Nezami HS, Chrevatidis A, Auriola S, Salminen S, Mykkanen H (2002) Removal of common Fusarium toxins in vitro by strains of Lactobacillus and Propionibacterium. Food Addit. Contam. 19: 680-686.

[116] Samar MM, Neira MS, Resnik SL, Pacin A (2001) Effect of fermentation on naturally occurring deoxynivalenol (DON) in Argentinean bread processing technology. Food Addit. Contam. 18: 1004-1010.

[117] Neira MS, Pacin AM, Martinez EJ, Molto G, Resnik SL (1997) The effects of bakery processing on natural deoxynivalenol contamination. Int. J. Food Microbiol. 37: 2125.

[118] Garda J, Macedo RM, Faria R, Bernd L, Dors GC, Badiale-Furlong RE (2005) Alcoholic fermentation effects on malt spiked with trichotecenes. Food Control. 16: 423-428.

[119] Yiannikouris A, Jouany J (2002) Mycotoxins in feed and their fate in animals: a review. Anim. Res. 51: 81-99.

[120] Hanschmann G, Krieg D (2006) The fate of Fusarium toxins in the course of the synthesis of bioethanol from contaminated grain. Mycotoxin Res. 22: 174-177.

[121] Bennett GA, Richard JL (1996) Influence of processing on Fusarium mycotoxins in contaminated grains. Food Technol. 50: 235-238. 
[122] Schaafsma AW, Limay-Rios V, Paul DE, Miller JD (2009) Mycotoxins in fuel ethanol co-products derived from maize: a mass balance for deoxynivalenol. J Sci. Food Agric. 89: 1574-1580.

[123] Scott PM (1992) Fermentation of wort containing deoxynivalenol and zearalenone. Mycotoxin Res. 8: 58-66.

[124] Böhm-Schraml M, Stettner G, Geiger E (1997) Studies into the influence of yeast on Fusarium toxins in wort. Cereal Res. Comm. 25: 729-730.

[125] Del Prete V, Rodriguez H, Carrascosa AV, Rivas BDL, Garcia-Moruno E, Munoz R (2007) In vitro removal of ochratoxin A by wine lactic acid bacteria. J. Food Protect. 70: 2155-2160.

[126] Niderkorn V, Boudra H, Morgavi DP (2006) Binding of Fusarium mycotoxins by fermentative bacteria in vitro. Appl. Environ. Microb. 101: 849-856.

[127] Rotter RG, Marquardt RR, Frohlich AA, Abramson D (1990) Ensiling as a means of reducing ochratoxin A concentrations in contaminated barely. J. Sci. Food. Agric. 50: 155-66.

[128] Dutton MF, Westlake K, Anderson MS (1984) The interaction between additives, yeasts and patulin production in grass silage. Mycopathologia. 87: 29-33.

[129] Camilo SB, Ono CJ, Ueno Y, Hirooka EY (2000) Anti-Fusarium moniliforme activity and fumonisin biodegradation by corn and silage microflora. Arquivos de Biologia e Tecnologia. 43: 159-64.

[130] Devegowda G, Raju MVLN, Afzali N, Swamy HVLN (1998) Mycotoxin picture worldwide: Novel solutions for their counteraction. In: Lyons TP, Jacques KA, editors. Biotechnology in feed industry. Nottingham: Nottingham University Press. pp. 241-255.

[131] Devegowda G, Arvind BIR, Morton MG (1996) Saccharomyces cerevisiae and mannanoligosaccharides to counteract aflatoxicosis in broilers. Proceedings of Australian poultry science symposium. Sydney. pp. 103-106.

[132] Raymond SL, Smith TK, Swamy HVLN (2003) Effects of feeding a blend of grains naturally contaminated with Fusarium mycotoxins on feed intake, serum chemistry, and hematology of horses, and the efficacy of polymeric glucomannan mycotoxin adsorbent. J. Anim. Sci. 81: 2123-12130.

[133] Karaman M, Basmacioglu H, Ortatatli M, Oguz H (2005) Evaluation of the detoxifying effect of yeast glucomannan on aflatoxicosis in broilers as assessed by gross examination and histopathology. Brit. Poultry Sci. 46: 394-400.

[134] Khatibi PA, Newmister SA, Rayment I, McCormick SP, Alexander NJ, Schmale DG (2011) Bioprospecting for trichothecene 3-o-acetyltransferases in the fungal genus fusarium yields functional enzymes with different abilities to modify the mycotoxin deoxynivalenol. Appl. Environ. Microbiol. 77: 1162-1170.

[135] Ingledew WM (1999) Yeast-Could you base a business on this bug? In: Lyons TP, Jacques KA, editors. Biotechnology in the Feed Industry. Nottingham: Nottingham University Press. pp.27-47. 
[136] Stone CW (1998) Yeast Products in the Feed Industry: A Practical Guide for Feed Professionals. Cedar Rapids, IA: Diamond V Mills Inc.

[137] Wu F, Munkvold GP (2008) Mycotoxins in ethanol co-products: modeling economic impacts on the livestock industry and management strategies. J. Agric. Food. Chem. 56:3900-3911.

[138] Mielenz JR (2001) Ethanol production from biomass: technology and commercialization status. Curr. Opin. Microbiol. 4:324-329.

[139] Madson PW, Monceaux DA (1995) Fuel ethanol production. The Alcohol Textbook. pp. 227-238.

[140] Bennett GA, Lagoda AA, Shotwell OL, Hesseltine CW (1981) Utilization of zearalenone-contaminated corn for ethanol production. J. Am. Oil. Chem. Soc. 58: 974976.

[141] Niessen L, Donhauser S (1993) Fate of deoxynivalenol in the process of brewing and its prevalence in commercial beer. In: Scudamore KA, editor. Proceedings of UK Workshop Occurrence and Significance of Mycotoxins, Slough, Central Science Laboratory, MAFF. pp. 203-207.

[142] Scott PM, Lawrence GA (1995) Analysis of beer for fumonisins, J. Food Prot. 58: 13791382.

[143] Scott PM, Lawrence GA (1997) Determination of aflatoxins in beer. J. AOAC Int. 80: 1229-1234.

[144] Baxter ED (1996) The fate of ochratoxin A during malting and brewing. Food Addit. Contam. 13(suppl): 23-24.

[145] Hanschmann G, Krieg D (2006) The fate of Fusarium toxins in the course of the synthesis of bioethanol from contaminated grain. Mycotoxin Res. 22: 174-177.

[146] Böswald C, Engelhardt G, Vogel H, Wallnöfer PR (1995) Metabolism of the Fusarium mycotoxins zearalenone and deoxynivalenol by yeast strains of technological relevance. Nat. Toxins. 3: 138-144.

[147] Boeira LS, Bryce JH, Stewart GG, Flannigan B (1999) Inhibitory effect of Fusarium mycotoxins on growth of brewing yeasts. 2. Deoxynivalenol and nivalenol. J. Inst. Brew. 105: 376-381.

[148] Whitehead MP, Flannigan B (1989) The Fusarium mycotoxin deoxynivalenol and yeast growth and fermentation. J. Inst. Brew. 95: 411-413.

[149] Wang J, Pawelzik E, Weinert J, Wolf GA (2005) Impact of Fusarium culmorum on the polysaccharides of wheat flour. J. Agric. Food. Chem. 53: 5818-5823.

[150] Maloney DH, Foy JJ (2003) Yeast Fermentations. In: Kulp K, Lorenz K, editors. Handbook of Dough Fermentations. New York: Marcel Dekker Inc. pp.43-102.

[151] Reinehr CO, Furlong EB (2003) Profile of the alcohols produced in fermentations with malt contaminated with trichothecenes. Braz. Arch. Biol. Technol. 46: 587-593.

[152] Flesch P, Voight-Scheuerman I (1994) Über den Abbau der Pilztoxine Trichotecin und Iso-Trichotecin bei der alkoholischen Garung in Traubensaft. Wein und Weinwissenschaft. 49: 180-184 
[153] Khatibi PA, Montanti J, Nghiem NP, Hicks KB, Berger G, Brooks WS, Griffey CA, Schmale DG (2011) Conversion of deoxynivalenol to 3-acetyldeoxynivalenol in barleyderived fuel ethanol co-products with yeast expressing trichothecene 3-Oacetyltransferases. Biotechnol. Biofuels. 4:26 doi:10.1186/1754-6834-4-26 